\title{
CIVIL REMEDIES FOR INTELLECTUAL PROPERTY INVASIONS: THEMES AND VARIATIONS
}

\author{
RaLPH S. BROWN*
}

\section{INTRODUCTION}

Both practitioners and students of intellectual property may benefit by exposure to comparisons of the overall remedial schemes of the three statutes $^{1}$ that encompass copyrights, patents, and trademarks. ${ }^{2}$ Such a survey $^{3}$ is further warranted by my belief that, in general, we do not pay enough attention to remedies. They come at the end of the road (with, of course, the major exception of preliminary relief) and, for most of us, do not have the intellectual challenge of determining the existence of rights. Yet remedies are the payoff in litigation. Their potential severity, or lenity, presumably influences business decisions. The risk of treble damages if one skirts a patent too closely, or of a crippling injunction if a marketing program

Copyright $\odot 1992$ by Law and Contemporary Problems

* Simeon E. Baldwin Professor of Law, Emeritus, Yale Law School; Adjunct Professor, New York Law School.

I warmly thank my learned friends of the New York City Bar, James W. Dabney, Esq., and Lloyd McAulay, Esq., for helpful comments.

I am happy to have been invited to join in acclaiming Robert Kastenmeier's remarkable contributions to the law of intellectual property. During his long service as member and Chair of the House subcommittee, he left his imprint on major legislation. Just as important, he used his position to discourage unwise proposals. At a time when Congress is in low esteem, his thirty-four years of steady statesmanship shine like a beacon.

1. The Copyright Act of 1976, as amended, comprises title 17 of the U.S. Code (1988). The Patent Act, codified in 1952, is found at 35 U.S. Code (1988). The Trademark Act of 1946 (the Lanham Act), revised in 1988, is found in $\$ \S 1051-1127$ of 15 U.S. Code (1988).

2. The judge-made law of trademarks and unfair competition preceded the statutes. Common law and statutes run almost parallel in substantive outline. The Lanham Act does offer enhanced damages. 15 USC $\$ 1117$. See text at note 200. Punitive damages as a common law remedy in unfair competition will be fleetingly noticed in Part VIC, see text at note 231. There are also state unfair trade practices and consumer protection statutes covering much of the same ground. Such statutes do not offer remedies to injured competitors, but rather to the state attorneys general and to consumers. See Paul Goldstein, Edmund W. Kitch \& Harvey S. Perlman, Selected Statutes and International Agreements on Unfair Competition, Trademark, Copyright and Patent 1-15 (Foundation Press, 1989).

3. This exercise, because of its scope, is unavoidably superficial. I have accordingly been especially dependent upon the leading treatises. I gratefully acknowledge help from Paul Goldstein, Copyright: Principles, Law and Practice (Little Brown, 1989, Supp 1991); Donald S. Chisum, Patents (Matthew Bender, 1978); Jerome Gilson, Trademark Protection and Practice (Matthew Bender, 1988); J. Thomas McCarthy, Trademarks and Unfair Competition (Law Co-op, 1984); Melville B. Nimmer \& David Nimmer, Nimmer on Copyright (Matthew Bender, 1991). I have wholly neglected criminal sanctions and trade secrets, as to which see William F. Johnson, Jr., Remedies in Trade Secrel Litigation, $82 \mathrm{Nw}$ U L Rev 1004 (1978). 
runs into an existing trademark, ought to affect the advice of lawyers, as well as the decisions of entrepreneurs.

The comparison will proceed from injunctive remedies, both before and after trial, to the varying forms of monetary recoveries: actual damages (which are usually plaintiffs' lost profits, or reasonable royalties), defendants' profits, statutory substitutes for actual damages, and enhanced and punitive damages. Each type of remedy is subdivided among copyrights, patents, and trademark. Recovery of lawyers' fees by either party in copyright cases is the topic of another contribution to this symposium, by Professor Peter Jaszi.4 Fees in patent and trademark cases are not addressed here.

This comparison seeks to survey the dominant similarities and disparities among the various remedies, illustrating the variations that have developed over a century or more. Occasionally, the comparison will linger somewhat on contentious matters, notably the conflict between the copyrights of some authors and the first amendment privileges of other authors. ${ }^{5}$

\section{II}

\section{Preliminary Injunctive Relief}

Professor Alan Latman tersely summed up the availability of preliminary injunctions in 1970: "In copyright cases, such relief is often close to automatic; in patent cases, it is close to impossible; in trademarks and unfair competition, it depends."6 The survey undertaken here will show a current marked relaxation of preliminary injunction standards in patent cases and a tilt toward granting preliminary injunctions in trademark/unfair competition cases.

The plaintiff who gets a preliminary injunction has a tremendous advantage. The defendant is stopped dead in his tracks. ${ }^{7}$ Even if the presentation of the two sides is confined to affidavits, depositions, and exhibits, ${ }^{8}$ the court has given a clear signal that it believes the plaintiff is likely to prevail. The grant of the preliminary injunction may be followed by explicit judicial nudges toward settlement. The defendant can certainly see ominous handwriting on the wall: thou hast been weighed in the balance and

4. Peter Jaszi, 505 and All That-The Defendant's Dilemma, 55 L \& Contemp Probs 107 (Spring 1992).

5. See part IIIA of this article.

6. Alan Latman, Preliminary Injunctions in Patent, Trademark and Copyright Cases, 60 Trade-Mark Rptr 506 (1970).

7. On the frequently decisive effect of a preliminary injunction in trademark cases, see Gilson, Trademark Protection and Practice $\$ 8.07[1]$ at 8-134 (cited in note 3).

8. Since federal jurisdiction is exclusive in copyright and patent cases, 28 USC $\$ 1338$ (b) (1988), and freely available in Lanham Act cases, 28 USC $\$ 1338$ (a) (1988), most litigation is governed by the Federal Rules of Civil Procedure and by Rule 65 for preliminary injunctions. Oral testimony may be required if facts are in dispute. See Charles A. Wright \& Arthur R. Miller, 11 Federal Practice E Procedure $\S 2949$ at 475 (West, 1973). The applicant for a preliminary injunction must post security against injury to the defendant during the span of the injunction if the defendant prevails. FRCP 65(c). From examples given in Wright \& Miller, these security bonds are not onerous in amount. Wright \& Miller, 11 Federal Practice and Procedure $\$ 2954$ at 526-27 (cited in this note). 
found wanting. It is a rare occurrence, especially when the grant of the preliminary injunction has been upheld by a court of appeals, for further reported litigation to occur. Since preliminary injunctions are almost routine in copyright cases that make the modest necessary showing, one would expect more copyright defendants to soldier on, in the hope of making a successful defense in a full trial. But it is my observation that they do not.

Those who seek preliminary injunctions still have to overcome the lingering notion that equitable remedies are extraordinary. To be sure, all of the controlling statutes provide for injunctions, but the patent and trademark statutes intone that injunctive relief flows "according to the principles of equity."9 This means that the litigants must show either that they have no adequate remedy at law ${ }^{10}$ or that irreparable harm will occur if the injunction does not issue.

A standard four-part test for a preliminary injunction asks:

(1) whether the plaintiff will have an adequate remedy at law or will be irreparably harmed if the injunction does not issue;

(2) whether the threatened injury to the plaintiff outweighs the threatened harm the injunction might inflict on the defendant;

(3) whether the plaintiff has at least a reasonable likelihood of success on the merits; and

(4) whether the granting of a preliminary injunction will disserve the public interest. ${ }^{11}$

The application of this "test," which has rather murky variations of form (and perhaps of substance) in the dominant Second ${ }^{12}$ and Ninth Circuits, ${ }^{13}$ is eased by the shortcut of creating a presumption of irreparable harm. To attain the shelter of such a presumption, the applicant need show only a reasonable likelihood of success on the merits. No strong connection between the notion of irreparable harm and a prediction of ultimate success

9. 15 USC $\$ 1116(\mathrm{a})$.

10. The present Copyright Act makes no reference to "the principles of equity." It only directs the court to set "such terms as it may deem reasonable." 17 USC $\S 502$ (a) An injunction remedy has been part of the statute since 1819 and until 1978 it also was to be granted "according to the course and principles of courts of equity." See William S. Strauss, Study No. 24, Remedies Other Than Damages for Copyright Infringement, in Copyright Society of USA, ed, 2 Studies in Copyright 1031 (Fred B. Rothman, 1963).

11. Atari, Inc. v North American Philips Consumer Electronics Corp., 672 F2d 607, 613 (7th Cir 1982). In an attempt to clear up the "disarray" he finds in the cases, both with respect to the standards themselves and the scope of review, Judge Posner has written two enormous opinions on the general requirements for a preliminary injunction. Roland Machinery Co. v Dresser Industries, Inc., 749 F2d 380 (7th Cir 1984); American Hospital Supply v Hospital Industries, Lld., 780 F2d 589 (7th Cir 1986). In both cases Judge Swygert vigorously dissented on the inconsequentiality of distinctions between "abuse of discretion" and "clear abuse of discretion," when reviewing trial court decisions. Such general discussions of equitable standards and discretion can be engrossing, but they are not very helpful in dealing with the separate worlds of intellectual property.

12. "[A] preliminary injunction can be granted if plaintiff shows irreparable injury, combined with either a probability of success on the merits, or a fair ground for litigation and a balance of the hardships in his favor." Wainwright Securities v Wall Street Transcript Corp., 558 F2d 91,94 (2d Cir 1977).

13. "To obtain a preliminary injunction, a party must show either (1) a likelihood of success on the merits and the possibility of irreparable injury, or (2) the existence of serious questions going to the merits and the balance of hardships tipping in its favor." Apple Computer, Inc. v Formula International, Inc., 725 F2d 521, 523 (9th Cir 1984). 
leaps to mind. No matter; courts do not often bother to demonstrate any such connection, nor to spell out why a plaintiff who does not get a preliminary injunction is, for the time being, left empty-handed. ${ }^{14}$

\section{A. Copyright}

One commentator believes that this presumption of irreparable harm explains the great ease of preliminary relief in copyright cases. ${ }^{15}$ Paul Goldstein, while expressing concern that courts may be too quick to grant "coercive relief" when the defendant's work consists only partly of infringing material, concedes that such caution is rarely observed. ${ }^{16}$ As a rationale for the ready presumption that damages may undercompensate he suggests: "copyright protects more than the author's strictly economic interests; her personal, aesthetic and reputational interests may also be at stake."17 Melville Nimmer suggests as an explanation the transitory value of most copyrights in such fields as "dramatic works, fabric designs and possibly video games." 18 But, as he demonstrates with clouds of citations, the rush to presume irreparable harm is not confined to such alleged ephemera. ${ }^{19}$

The most thorough recent appellate consideration of the four factors of the preliminary injunction test emphasizes their interdependence. In Concrete Machinery Co. v. Classic Lawn Ornaments, Inc. ${ }^{20}$ Concrete charged Classic with copying its lawn statuary-deer, swans, and such. Classic, in the brief preliminary injunction hearing, emphasized differences in the creatures. The trial court denied the injunction; the court of appeals reversed. In addition to expounding substantive principles for finding infringement, the court of appeals made its own positive appraisal of the plaintiff's likelihood of success, and cautioned against giving undue weight to expected hardship on the defendant if it was banned from the concrete lawn ornament business for the time being. Such solicitude, the court observed, would favor a defendant whose principal business was illicit copying. As for the public interest factor, the court said there was clearly a public interest in protecting copyrights, since Congress has beneficently authorized them. ${ }^{21}$ This is a conventional quick way of dealing with the public interest.

One emerges from all this weighing of imponderables with a sense that likelihood of success is the dominant factor. But if the defendant can take

14. This is the burden of Timothy J. McClimon, Denial of Preliminary Injunction in Copyright Infringement Cases: An Emerging Judicially Crafted Compulsory License, 10 Colum-VLA J L \& Arts 277 (1986). I do not share his view that courts too easily deny injunctions. His article is the helpful source of the various "standards" quoted above. Id at 292-93.

15. Note, Copyright Law-Likelihood of Success on the Merits Now Affects the Balance of Hardships in Actions for Preliminary Relief, 23 Suffolk U L Rev 1133, 1136 (1989) (authored by Jeffrey DiNicola).

16. Goldstein, 2 Copyright $\$ 11.10$ at 248 (cited in note 3 ).

17. Id at 249.

18. 3 Nimmer on Copyright $\S 14.06[\mathrm{~A}]$ at $14-85$ (cited in note 3 ).

19. Id at $14-86$

20. 843 F2d 600 (1st Cir 1988)

21. Id at 612. Compare J.R. O'Dwyer co v Editorial Media Marketing, 18 USPQ (BNA) 2d 1356 (SDNY 1991) (defendant directory publisher "struggling to establish a market niche"; preliminary injunction denied). 
arms to oppose a preliminary injunction, it is customarily asserted that the entire matter is entrusted to the discretion of the trial court. The trial court may and will deny the injunction ${ }^{22}$ if the plaintiff does not seem to have much of a case. Nevertheless, a persistent plaintiff, as in Concrete, can sometimes overcome the denial. Whatever the reasons, the copyright plaintiff has a distinct edge in a preliminary round that may turn out to be decisive.

\section{B. Patents}

Latman's "close to impossible" appraisal of the patent plaintiff's chances of getting preliminary relief had solid support in case law before 1970. Judge Learned Hand, with characteristic terseness, had written back in 1927 that "an injunction pendente lite in a patent case should not go except when the patent is beyond question valid and infringed."23 This attitude persisted, and was probably a reflection of the general low regard that many courts had long displayed for the patents that emanated from the Patent Office. ${ }^{24}$ Justice Jackson, in a notorious quip, said that "[t]he only patent that is valid is one which this Court has not been able to get its hands on."25

Attitudes toward patents began to change with the creation of the court of appeals for the Federal Circuit in 1982. That court was given exclusive appellate jurisdiction in all patent cases; its predecessor, the Court of Customs and Patent Appeals ("CCPA"), heard only appeals from the tribunals of the Patent and Trademark Office. Infringement and related matters had flowed to the eleven geographical courts of appeals and (once in a great while) to the Supreme Court. ${ }^{26}$

What appeared on the surface to be a jurisdictional shuffle resulted in the rehabilitation of the patent system. Buoyed up by a rising tide of public concern for innovation and competitiveness in world markets, the judges of the Federal Circuit have followed their own predilections, markedly improving the fortunes of patentees. Professor Dreyfuss, in the leading study of the court's work, depicts this dramatic shift toward upholding patents. ${ }^{27}$ She also observes that the Federal Circuit "has revitalized the role of preliminary injunctive relief in patent suits." 28

Decisions in the Federal Circuit's first decade have come to assert that the standards for preliminary relief are the same as in other areas of intellectual property; they currently invoke a version of the four-part formula recited

22. McClimon, 10 Colum-VLA J L \& Arts at 292-93 (cited in note 14), emphasizes such cases.

23. Simson Bros., Inc. v Blanchard छ Co., 22 F2d 498 (2d Cir 1927).

24. See Dan B. Dobbs, Handbook on the Law of Remedies $\$ 6.2$ at 436 (West, 1973).

25. Jungersen $v$ Ostby $\Xi$ Barton Co., 335 US 560, 572 (1949).

26. Rochelle C. Dreyfuss, The Federal Circuit: A Case Study in Specialized Courts, 64 NYU L Rev 1 (1989).

27. Id at 26; see also Robert P. Merges, Commercial Success and Patent Standards: Economic Perspectives on Innovation, 76 Cal L Rev 805 (1988) (Federal Circuit's receptivity to "secondary factors" enhances patentability). Robert L. Harmon, Patents and the Federal Circuit (BNA, 1988), surveys all the decisions.

28. Dreyfuss, 64 NYU L Rev at 19 (cited in note 26). 
above. ${ }^{29}$ But they do so still with some diffidence ${ }^{30}$ and with arguably higher thresholds of harm and likelihood of success than in copyright.

For example, Judge Giles Rich, the dean of the Federal Circuit, in supporting a preliminary injunction, wrote that the burden upon the movant (to justify a presumption of irreparable injury) "should be no different in a patent case than for other kinds of intellectual property, where, generally, only a 'clear showing' is required." 31 He then cites copyright cases where a "clear showing" of validity and infringement was indeed present. He and other judges who are loosening the bonds on plaintiffs in patent cases do not appear to appreciate how easily the presumption of irreparable harm is invoked in copyright. ${ }^{32}$

One advantage that the patent plaintiff now has stems from another act of rehabilitation in the patent system. The statute has since 1952 conferred a statutory presumption of validity upon patents. ${ }^{33}$ A patent has, after all, survived the Patent Office examining process. However, in the old days when litigated patents were invalidated far more frequently than they were sustained, the presumption of validity counted for little. ${ }^{34}$ This presumption is now "firmly established," 35 with the consequence that nowadays the burden of persuasion of invalidity rests firmly on the party challenging the patent. Moreover, the challenger must establish invalidity by clear and convincing evidence. ${ }^{36}$ So, while the presumption of validity does not by itself satisfy the requirements for preliminary relief, it is a favorable part of the context in which the injunction-seeker makes her case. ${ }^{37}$

In contrast, the copyright holder has a weak statutory presumption of prima facie validity of the facts recited in a copyright registration..$^{38}$ It is weak because the "facts" are simply what the applicant writes down as facts. It has nothing resembling the flourishing presumption of patent validity, and figures not at all in copyright preliminary injunction determinations. The availability of preliminary relief in patent cases, we may conclude, is rising remarkably.

29. See text accompanying note 11. The shift commenced with Smith International, Inc. $v$ Hughes Tool Co. 718 F2d 1573, 1577-79 (Fed Cir 1983), which, however, still showed considerable deference to "the more severe rule."

30. See Roper Corp. v Litton Systems, Inc, 757 F2d 1266 (Fed Cir 1985) (denying injunction for failure to show irreparable injury).

31. Atlas Powder Co. v Ireco Chemicals, 773 F2d 1230, 1233 (Fed Cir 1985).

32. But see the fairly relaxed interpretation of the Federal Circuit's preliminary injunction standards in Zeller Plastik, Koehn, Grabner E Co. v Joyce Molding Corp., 698 F Supp 1204, 1220 (D NJ 1988).

33. 35 USCA $\$ 282$ (1988). Nominally, the presumption already existed. See Judge Rich, a principal drafter of the 1952 Act, in American Hoist and Derrick Co. $v$ Sowa E Sons, 725 F2d 1350 (Fed Cir 1984).

34. Dreyfuss, 64 NYU L Rev at 6 n35 (cited in note 26).

35. Id at 21 .

36. American Hoist and Derrick, 725 F2d at 1360 .

37. H.H. Robertson Co. v United Steel Deck, Inc, 820 F2d 384, 388 (Fed Cir 1987). These trends are summed up in Southwest Aerospace Corp. v Teledyne Industries, Inc., 702 F Supp 870 (ND Ala 1988).

38. 17 USC $\$ 410(c)$. 


\section{Trademarks}

The plaintiff in a trademark infringement action generally wants the defendant to stop using a symbol that is likely to confuse customers. She would like the defendant stopped right away, before her market is eroded. The setting seems highly appropriate for preliminary relief, which, not surprisingly, is not hard to obtain. A reasonably strong showing of likely confusion may be made at the preliminary hearing either through side-by-side comparison of the trade symbols at issue or by introducing a customer survey. Such a showing will satisfy the irreparable harm limb of the conventional fourpart formula that by now is familiar.

There is nothing at all extraordinary about injunctive relief in trademark cases. It is the standard remedy. ${ }^{39}$ Indeed, the appropriateness of equitable relief, because of the difficulty of establishing monetary damages, is almost a platitude in trademark and other unfair competition cases. More will be said about this rationale in the later examination of monetary remedies.

Looking back from twenty years' accumulation of cases since Latman wrote, there seems to be little occasion for his ambiguous judgment that, when considering the availability of preliminary relief in trademark and unfair competition cases, "it depends." 40 It does depend on satisfying the usual formula, but it is easily satisfied. ${ }^{41}$

III

\section{Permanent Injunctions}

\section{A. Copyright}

Permanent injunctions are said to be a matter of course for a prevailing plaintiff, ${ }^{42}$ but two exceptions may be developing, or at any rate should be encouraged. One is auxiliary to the storm that blew up in the Second Circuit about the privilege of an author to quote from unpublished works of another author. ${ }^{43}$ Substantively, these thunderheads shadow a corner of fair use. If the challenged use is fair, it is not an infringement. ${ }^{44}$ May there be cases

39. Restatement of the Law of Unfair Competition, Tentative Draft No. $3 \S 35$ at 86 (Am L Inst, 1991) ("ALI Restatement")

40. Latman, 60 Trade-Mark Rptr at 605 (cited in note 6).

41. This conclusion rests largely on the ALI Restatement $\$ 35$ at $86-87$ (cited in note 39); Gilson, 1 Trademark Protection and Practice $\$ 8.07$ at 8.126 (cited in note 3); and McCarthy, 2 Trademark and Unfair Competition $\$ 30.15$ at 341 (cited in note 3 ).

42. 3 Nimmer on Copyright $\$ 14.06$ at $14-90$ (cited in note 3 ).

43. Salinger $v$ Random House, Inc., 811 F2d 90 (2d Cir 1987).

44. The judicial development of fair use is codified in 17 USC $\$ 107$, which is explicit that "fair use . . . is not an infringement . . . ." The Supreme Court considered fair use of an unpublished work, President Ford's memoirs, in Harper $\mathfrak{G}$ Row Publishers, Inc. v Nation Enterprises, 471 US 539 (1985), concluding that "the unpublished nature of a work is a "key, though not necessarily determinative, factor' tending to negate a defense of fair use," id at 554; the Court found that when the Nation "arrogated to itself the right of first publication," id at 549, in printing key excerpts from the memoirs, it did not satisfy the statutory standards. Harper \& Row did not seek an injunction, only the $\$ 12,500$ it lost when Time magazine, "scooped" by the Nation's clandestine access to the manuscript, cancelled its contract for first magazine publication. 
where the fair use privilege should be characterized as incomplete? That is, cases in which the complaining author may not have an injunction, but may recover damages. The second issue is similar. There are a few other infringement situations where it may be sound policy to withhold the injunction while assessing damages. A conspicuous recent instance is the "Rear Window" movie case that reached the Supreme Court.45 The Court affirmed the force of the renewal copyright's ownership, but left undiscussed the ingenious remedy proposed by the court of appeals: that the marginally deserving plaintiff ${ }^{46}$ could have a share of the profits from the popular movie, but no injunction.

The quotability of unpublished works, sharpened by two episodes in the Second Circuit (the reluctant sources were novelist J.D. Salinger ${ }^{47}$ and cultleader L. Ron Hubbard ${ }^{48}$ ), has elicited, in addition to the expectable flow of academic opinion, a perhaps unique torrent of extra-judicial comment from the judges 49 and legislative proposals that may have come to fruition (or decay) before this work is disseminated.50 The narrow question in quoting unpublished works is this: assuming that the window of permissible quotation from what are indiscriminately labelled "unpublished" 51 works is to be narrowly opened, should all the ventilation occur under the heading of fair use, which excuses copying that would otherwise be infringement? Those who reprehend the easy resort to injunctions in such cases tend to fall silent after urging fewer injunctions and more fair use. ${ }^{52}$ Justice Benjamin Kaplan, in his inexhaustible source of good sense, the Unhurried View of Copyright, did write that "courts have sometimes forgotten that an injunction does not go of course; the interest in dissemination of a work may justify a confinement of the remedy to a money recovery (just. as it may suggest the legislative use, in proper doses, of the device of a compulsory license)."53 But how do you measure the money recovery when the taking consists of a larger quota of revelations than a careful judge thinks allowable as fair use?

45. Stewart $v$ Abend, $110 \mathrm{~S}$ Ct 1750 (1990).

46. See text at note 63-64.

47. Salinger $v$ Random House, Inc., 811 F2d 90 (2d Cir 1987).

48. New Era Publications, Int'l v Henry Holt E Co., 873 F2d 576 (2d Cir 1989).

49. See citations in notes $52,54,57$, and 58 .

50. A weak amendment to section 107 that would not "bar a finding of fair use" from unpublished works passed the Senate by a voice vote on September 27, 1991. But on October 1, an identical provision was dropped from a package of amendments before the House Subcommittee. Its chairman opined that emerging developments in the Second Circuit would make it unnecessary. See 42 Patent Trademark \& Copyright J (BNA) 520-23 (Oct 3, 1991).

51. To speak of "fair use of unpublished works" as if the cases were all essentially the same, overlooks the gulf between Salinger's letters, which the addressees had deposited in university research libraries, and Hubbard's journals and letters, some of which may have reached the biographer through illicit channels. See text accompanying note 71 .

52. Perhaps one can mildly fault the elegant lecture by Judge James Oakes for not developing this minor theme. James Oakes, Copyright and Copy Remedies: Unfair Use and Injunctions, 18 Hofstra L Rev 983 (1990). However, the lecture did direct me to the passage from Justice Kaplan, id at 994 $\mathrm{n} 52$, and it is invaluable on the larger issues attending injunctions. The Oakes lecture is relied upon for the denial of permanent injunction in Love $v$ Kwitny, 2 Copyright L Rptr (CCH) 96,789 (SDNY 1991).

53. Benjamin Kaplan, An Unhurried View of Copyright 73 (Columbia U Press, 1967). 
Judge Leval in the L. Ron Hubbard dispute did opine that the biographer had overstepped-somewhat. But the unexpected disposition of the case-its dismissal for hurtful delay in bringing it-left unresolved precisely what Judge Leval would have done about the excessive takings. It is clear he believed an award of damages would be appropriate. ${ }^{54}$ What kind of damages? There is a plenitude of choice in copyright-actual damages, statutory damages, or a share of defendant's profits. Actual damages from taking bits and pieces from unpublished writings would be almost impossible to establish. How much of defendant's profits could be attributed to a margin of copying beyond fair use also seems rather conjectural. Statutory damages would likely be more appropriate.

The claim of fair use of unpublished writings is of acute interest to aficionados of fair use, but probably of infrequent occurrence. ${ }^{55}$ Under conventional doctrines, "facts" and "ideas" in unpublished works are never protected by copyright. Fair use even permits taking a limited portion of the author's expression when necessary for accurate reporting of factual material. ${ }^{56}$ Then there is a stratum of copying that does not call for injunctive relief, but will attract monetary recovery. How wide it is nobody knows; but, as a result of good-tempered withdrawals from exposed positions, even Judge Miner (who wants the fair use window to be closed), ${ }^{57}$ wrote for the court in denying en banc rehearing of the L. Ron Hubbard case that "[a]ll now agree that injunction is not the automatic consequence of infringement." 58

The limited scope of fair use of undisseminated writings, especially when the unavailable material illuminates the lives of public figures-a President, a major novelist, a powerful cult leader-illustrates the sometimes painful tension between copyright and the first amendment. The biographer or journalist has almost within her grasp illuminating material that cries for publication. The copyright owner resists and has the copyright law on her side. The tension becomes almost unbearable when the copyright holder threatens an injunction, because one begins to smell the most offensive of obstacles to speech, the prior restraint. Pages of history preach the wickedness of prior restraints on publication, ${ }^{59}$ yet that is precisely what an injunction does.

The conventional response of courts, when the first amendment confronts copyright, is to say that the fair use privilege eases any tension. That

54. New Era Publications Intl v Henry Holt É Co., 695 F Supp 1493, 1523 (SDNY 1988). Pierre Leval, Toward a Fair Use Standard, 103 Harv L Rev 1105, 1131-32 (1990), further develops the arguments for occasionally refusing injunctions, with references at note 112 .

55. Leval, $103 \mathrm{Harv}$ L Rev at $1134 \mathrm{nl} 23$ (cited in note 54), comments on the rarity of such instances in his dealing with 150-200 copyright cases in 12 years on the bench.

56. Jon O. Newman, Not the End of History: The Second Circuit Struggles with Fair Use, $37 \mathrm{~J}$ Copyright Society of USA 13, 14-15 (1989).

57. Roger Miner, Exploiting Stolen Text: Fair Use or Foul Play, $37 \mathrm{~J}$ Copyright Society of USA 1 (1989).

58. New Era, $884 \mathrm{~F} 2 \mathrm{~d}$ at 661 .

59. See, for example, New York Times v United States, 403 US 713 (1971) (the "Pentagon Papers" case). 
response, further lubricated by the freedom to appropriate facts and ideas, takes care of most situations, ${ }^{60}$ but not that of the writer barred from using unpublished material.

The other escape from an injunction, represented by the "Rear Window" case, avoids constitutional emanations. The plaintiff claimed as assignee of the renewal copyright term under the old statute, still very much alive in this regard. ${ }^{61}$ The defendant's film was a derivative work licensed during the first term. Did the end of the first term end the license? There was respectable authority both ways. ${ }^{62}$ The Supreme Court reached the correct result ${ }^{63}$ and affirmed the view of the court of appeals that the license was no longer valid. Did that entitle Abend, who was rather a speculator in renewal copyrights, to have an injunction that would stop the exhibition of "Rear Window" except on whatever terms he might set? No, said the court of appeals (the Supreme Court did not speak to the remedy issue). The value of the movie flowered in large part because Alfred Hitchcock directed it, while Jimmy Stewart and Grace Kelly were its stars. ${ }^{64}$ Abend, the copyright owner, was entitled to no more than a generous apportionment of the movie's profits (it received a new life when re-released in 1980).

This is the correct method of administering an award of profits and likely the right way to dispose of this case. The same court (though through a different panel) had made an earlier try at withholding an injunction. That was in the famous Betamax case, on the legality of making cassettes of copyrighted telecast movies for the convenience of shifting one's viewingtime. The court of appeals differed with the district court and (more decisively) with the Supreme Court. ${ }^{65}$ It held that the provision of equipment for that purpose constituted contributory infringement. It suggested that the district court consider, instead of an injunction, a "continuing royalty," presumably on machines and blank tapes. ${ }^{66}$

60. See cases and articles cited in Ralph S. Brown \& Robert C. Denicola, A Note on Copyright and the First Amendment, in Brown \& Denicola, eds, Cases on Copyright 343-45 (Foundation Press, 1990); Diane Zimmerman, Information as Speech, Information as Goods: Some Thoughts on Marketplaces and the Bill of Rights, 33 Wm \& Mary L Rev 665 (1992).

61. Works created before January 1, 1978 (the effective date of the present statute) continue to have a first term of 28 years and are eligible for a renewal term of 47 years. Works already in the renewal term on January 1 , 1978 (as was the copyright construed in $A b e n d$ ) were extended to a total duration of 75 years. 17 USC $\$ 304(a)$, (b).

62. Miller Music Corp. v Charles N. Daniels, Inc., 362 US 373 (1960), and G. Ricordi E Co. v Paramount Pictures, Inc., 189 F2d 469 (2d Cir 1951), support the plaintiff's position. Rohauer $v$ Killiam Shows, Inc., 551 F2d 484 (2d Cir 1977), was very close to the defendants', but it was repudiated by the court of appeals and the Supreme Court in the "Rear Window" opinions.

63. But compare Barbara A. Allen \& Susan R. Swift, Shattering Copyright Law: Will James Stewart's Rear Window Become a Pain in the Glass?, 22 Pac L J 1 (1990); Donald A. Hughes, Jurisprudential Vertigo: The Supreme Court's View of "Rear Window" is for the Birds, 60 Miss L J 239 (1990).

64. Abend v MCA, Inc., 863 F2d 1465, 1478 (9th Cir 1988).

65. Universal City Studios, Inc, $v$ Sony Corp. of America, 480 F Supp 429 (CD Cal 1979) (no infringement), rev'd 659 F2d 963 (9th Cir 1981), rev'd 464 US 417 (1984).

66. "This may very well be an acceptable resolution in this context." Sony Corp, 659 F2d at 976. 
This would have been a bold remedy indeed. Without legislative authorization, ${ }^{67}$ it would have created a compulsory license that all parties would have had to accept. The "Rear Window" direction did this as well, as would a case denying fair use but permitting the use of unpublished (or for that matter, published) writings on payment of damages. Likewise, cases that denied an injunction but afforded prospective monetary recovery would have been of the same ilk.

The notion that you can deal with infringement by meeting a schedule of payments is not unknown to copyright law. Obviously and pervasively, voluntary licenses take care of millions of transactions, especially when one considers the long reach of performing rights societies and their rivals. ${ }^{68}$ Then, there are four kinds of compulsory licenses blessed by the statute. ${ }^{69}$ Professor Jane Ginsburg, in proposing to add a fifth (for informational works of low-level authorship), concedes that "compulsory licensing is not a favored technique in copyright law. It is a form of price regulation, and price regulation is generally considered administratively cumbersome, unlikely to arrive at a 'correct' rate, and contrary to copyright's overall free market philosophy."70 Perhaps there is a niche for ad hoc judicial licenses to copyat a judicially set price? These avoid cumbersome administration and all controls except the ad hoc decisions of judges.

It appears that the equitable slogans about irreparable harm and inadequate legal remedies can and should be brushed aside and injunctions denied in four borderline situations. First, the law should recognize a narrow window of some copying from unpublished works beyond the boundaries of fair use, controlled always by the circumstances. One should first ask, how did the copier come by the material? As Judge Miner reminds us, the damaging Hubbard papers almost surely reached the biographer through channels that had an illegal origin. ${ }^{71}$ By contrast, Salinger's letters were accessible in university libraries, deposited there by such eminent correspondents as Learned Hand. Judge Miner, ordinarily the unyielding foe of fair use of unpublished material, seems to consider such letters "disseminated" and open to quotation. ${ }^{72}$ What about the plaintiff's cries that the biographer or journalist is invading his privacy? Is copyright a proper vehicle for protecting privacy? Judge Newman thinks so; ${ }^{73}$ Judge Leval differs. ${ }^{74}$ One consideration

67. Marshall A. Leaffer, The Betamax Case: Another Compulsory License in Copyright Law, 3 U Toledo L Rev 651, 680 (1982), was sympathetic to the compulsory license, but believed that it should be legislated. Of course, Sony's success in the Supreme Court disposed of the problem.

68. See Brown \& Denicola, eds, Cases on Copyright at 470-78 (cited in note 60).

69. Id at 494-509.

70. Jane C. Ginsburg, Creation and Commercial Value: Copyright Protection of Works of Information, 90 Colum L Rev 1865, 1924 (1990).

71. Miner, $37 \mathrm{~J}$ Copyright Society of USA at 5 (cited in note 57). But compare Edmund Kitch \& Harvey S. Perlman, Legal Regulation of the Competitive Process 732-33 (Foundation Press, 1991) (skeptical of Judge Miner's characterization).

72. Miner, $37 \mathrm{~J}$ Copyright Society of USA at 11 (cited in note 57).

73. Jon O. Newman, Copyright Law and the Protection of Privacy, 12 Colum-VLA J L \& Arts 459 (1984).

74. Leval, 103 Harv L Rev at 1119 (cited in note 54). 
is that privacy rights do not (yet) survive the claimant. ${ }^{75}$ There are several ways to bore into the privacy claims, all within the grasp of a sensitive chancellor. ${ }^{76}$

Second, the Abend-Stewart-Rear Window litigation offers a way to spare the makers of valuable derivative works from total vanquishment by an injunction at the hands of the owner of renewal copyright in the underlying work. The new statute takes care of this; it has an exception to its new termination right that permits a derivative work to "continue to be utilized."77 But we still have thirty-odd years before the last old renewal right rides off into the sunset.

Third, withholding an injunction may be highly appropriate when infringements do not pervade the defendant's work, yet cannot be excised. For example, suppose that a book is already printed. Injunction, impoundment, and destruction ${ }^{78}$ are a heavy-handed approach. To invoke laches, as in the L. Ron Hubbard case, thus giving the plaintiff nothing, is equally heavy-handed.

Finally, there may be instances, like the Sony Betamax case, where brute public pressure to open up a technology may call for dividing the pie rather than preferring one party to another. ${ }^{79}$ None of these four scenarios should occur often enough to overload judicial capacities. ${ }^{80}$

\section{B. Patents}

Permanent injunctions in favor of a prevailing patentee are so thoroughly a matter of course that Professor Chisum does not even discuss them in his leading multi-volume scholarly treatise. ${ }^{81}$ What, if anything, is of interest? There are cases that allow withholding the injunction where infringement had

75. Restatement (Second) of Torts $\$ 652 D$, comment i (Am L Inst, 1977).

76. Leval, 103 Harv $L$ Rev at $1119 \mathrm{n} 67$ (cited in note 54).

77. 17 USC $\S 203(b)(1)$. All grants made after January 1,1978 (other than by will) are subject to termination after 35 years. The exception referred to is intended to safeguard producers ' interests in old movies, and to spare them from what almost happened to Stewart and the other defendants in the Rear Window case.

78. Impoundment and destruction of offending copies provided for in 17 USC $\S 503$ are within the court's discretion. Such dispositions can be harsh. See J. Marc Alexander, Discretionary Power to Impound and Destroy Infringing Articles: An Historical Perspective, $29 \mathrm{~J}$ Copyright Society of USA 479 (1982); Paul S. Owens, Impoundment Procedures under the Copyright Act: The Constitutional Infirmities, 14 Hofstra L Rev 211 (1985).

79. An example may be the introduction of digital audio taping (DAT) with a legislated compulsory royalty on machines and tapes. 42 Patent, Trademark \& Copyright J (BNA) 329 (Aug 8 , 1991).

80. A decision that came down while this article was in progress makes large claims for first amendment influence on the scope of injunctions. In Cable News Network, Inc. $v$ Video Monitoring Services of America, 940 F2d 1471 (11 th Cir), the defendant monitored all of plaintiff's programs, and sold selected copies to advertisers and other interested buyers. CNN had not licensed VMS; it licensed another monitoring company. CNN registered its copyright on one segment of "Crossfire," sued VMS for infringement, and obtained a sweeping preliminary injunction that forbade any copying of plaintiff's broadcasts. This decision was reversed as overbroad in that it attempted to restrict copying of future broadcasts that could not yet have copyright because they had not yet been created, and in any event would be full of uncopyrightable factual news. The panel decision has been vacated and set for reargument en banc. 43 Patent, Trademark \& Copyright J (BNA) 115 (Dec 12 , 1991).

81. Chisum, Patents (cited in note 3). 
ceased and was unlikely to resume. ${ }^{82}$ A lively short practitioner's piece by Herbert Schwartz is instructive. ${ }^{83}$ There is a little pocket of cases where the patentee was not working the patent and the infringer was dependent on it; a compulsory license was in effect created, and the injunction withheld. ${ }^{84}$ But it was an abuse of discretion to spare one of several infringing makers of sailboards because his enterprise was such a little one; and it got the defendants nowhere to plead that the patent had only a year to run, or only three months. The injunctions came down nevertheless. ${ }^{85}$

Schwartz also reports on the decline of a practice of allowing stays of injunction pending an appeal. The grounds for the infringers' getting such a stay were just the reverse of those for getting an injunction-a showing of no irreparable harm to the patentee, etc. The real motive was to buy time, and to hope that the patent on appeal would be found invalid or not infringed. ${ }^{86}$ The new severity against infringers was dramatized in the great case in which Polaroid knocked Eastman out of the instant camera business. The stay was denied; Eastman appealed the denial; within weeks the Federal Circuit upheld the denial, as did the Circuit Justice. The next day Eastman gave up. ${ }^{87}$

\section{Trademarks}

Because an injunction is the primary remedy for trademark infringements, the successful plaintiff, whether or not she has sought preliminary relief, will routinely get a permanent injunction. These may differ from copyright and patent injunctions. The copyright infringer has copied from an identified specific work or works of the plaintiff. The injunction will tell him to copy no more, or to stop performing an identified musical or dramatic work. Only occasionally is there ambiguity as to what is protected. ${ }^{88}$ Likewise with patents. The infringer ordinarily is manufacturing or selling something identifiably similar to the subject of the plaintiff's patent. If she attempts to circumvent an injunction by altering her product-but not enough-that would be the occasion for a contempt citation. ${ }^{89}$

82. Albert H. Walker, 7 Lipscomb's Walker on Patents $\$ 25: 35$ at 347 (Law Co-op, 1989).

83. Herbert F. Schwartz, Injunctive Relief in Patent Cases, 50 Albany L Rev 565 (1986).

84. Id at 566; Foster v American Mach E Foundry Co., 492 F2d 1317 (2d Cir 1974).

85. Schwartz, 50 Albany L Rev at 571 (cited in note 83).

86. Id at 572 .

87. Id at 573-74.

88. With regard to copyrightable cartoon characters (of the Superman genre), is it the character simply as depicted, beyond a rather simple delineation of a man in tights and a cape, or the character performing certain feats that establish his protectable content? The Second Circuit wrestled with this twice, speaking through the two Judges Hand. Judge Augustus Hand said that the plaintiff must show copying of some "incidents and literary expressions." Detective Comics, Inc. $v$ Bruns Publications, Inc., 111 F2d 432, 433 (2d Cir 1940). Judge Learned Hand went a step further and required a stripby-strip analysis. National Comics Publications, Inc. v Fawcett Publications, Inc., 198 F2d 927 (2d Cir 1952). On the other hand, the Seventh Circuit seemed to accept the Pac-man figures on $T V$ games as protectable just from their appearance. Atari $v$ North American Philips Consumer Electronics Corp., 672 F2d 607, 619 (7th Cir 1982).

89. What happens in contempt proceedings seems to get little attention either from commentators or in reported decisions. For discussion of contempt proceedings in patent cases see Harmon, Patents and the Federal Circuit at 403-08 (cited in note 27). 
In contrast, a challenged trademark may be confusing in some contexts, but not in others. Accordingly, the injunction must often be qualified to delineate what may be forbidden and what permitted.90 $\mathrm{A}$ traditional way of minimizing confusion has been to require disclaimers by the defendant of any confusing connection with the plaintiff. A fanciful (but probably ineffective) example:

Tiffany Hairbrush

Not connected with Tiffany \& Co.

Fifth Ave., New York

Considerable skepticism has developed over the years: maybe disclaimers are themselves confusing. Commentators report a decline in their acceptance as a way out of liability, ${ }^{91}$ but there are still occasions on which they can contribute to a fair solution. A qualified injunction can state precisely how a disclaimer must read.

The circumstances that call for a qualified injunction are many. There are only a few broad categories that implicate major substantive issues in trademark law. First, is the defendant selling something that the plaintiff also sells or does the challenged product (or service) not directly compete, as for example, a Tiffany car wash? This might still be a preventable use, because it might be thought to imply, falsely, sponsorship by Tiffany; Tiffany is a highly distinctive mark because of its long association with luxury jewelry. ${ }^{92}$ This would ordinarily call for a yes-or-no decision, but it might be amenable to a disclaimer.

Suppose that someone named Tiffany wanted to give his name to a jewelry store. This again might be an appropriate case for requiring the newcomer to use his given name plus a disclaimer. Nowadays, courts are highly skeptical of the claim of people who want to use a famous name, even if it is also their own. ${ }^{93}$

It is fundamental in trademark law that generic names cannot be appropriated. Yet the capacities of qualified injunctions may also assist the first user of a symbol that has become generic. "Aspirin" for the familiar pain-reliever and "thermos" for vacuum bottles became generic, but the first users were not entirely wiped out. Judge Learned Hand decided that Bayer could still have exclusive rights to the "aspirin" label in the wholesale (but not the retail) trade; 94 and a later court preserved the distinctive logo of the

90. This section draws largely on ALI Restatement $\& 35$, comments $c$ and d (cited in note 39).

91. Jacob Jacoby \& Robert L. Reaskoff, Disclaimers in Trademark Infringement Litigation: More Trouble Than They are Worth?, 76 Trademark Rptr 35 (1986); Mitchell E. Radin, Disclaimers as a Remedy for Trademark Infringement: Inadequacies and Alternatives, 76 Trademark Rptr 59 (1986), cited in Home Box Office v Showtime, 832 F2d 1311, 1316 (2d Cir 1987). A careful recent decision suggesting that a disclaimer might be appropriate is Jim Beam Brands Co. $v$ Beamish $\xi$ Crawford, Ltd., 937 F2d 729, 737 (2d Cir 1991).

92. See, for example, Tiffany \& Co. v Tiffany Tile Corp., 345 F2d 214, 215 (CCPA 1965). 3).

93. See generally McCarthy, 2 Trademarks and Unfair Competition ch 13 at 577 et seq (cited in note

94. Bayer Co. v United Drug Co., 272 F 505, 515 (SDNY 1921). 
American Thermos Co., even though the word "thermos" became open for competitors to use. ${ }^{95}$

Another circumstance that requires adjustment of rival interests occurs when the same mark develops in different parts of the country. This has its own complexities ${ }^{96}$ and is mentioned here only as one more example of the need to tailor injunctions.

Finally, the rise of advertising and marketing practices that make explicit and unfavorable reference to competing products stirs quarrels about whether the comparison is a legitimate non-trademark use of another's trademark, or whether the name of the (usually more expensive) product will confuse buyers into thinking that they are being offered the more costly brand at a reduced price. If there is an injunction, it must be framed with great particularity, and may lead to repeated trips back to court on contempt charges if the defendant is persistent. ${ }^{97}$

These hasty forays into the contentious substance of trademark law show that the framing of injunctions (preliminary or permanent) often demands more discriminating adjustments than are usually necessary in copyright and patent. One overriding observation: if the court is convinced that the defendant is exploiting the plaintiff's mark "in bad faith"-a phrase encrusted with equitable barnacles-it will probably not bother with the refinements suggested.98 An injunction will issue absolutely banning defendant's use of the mark.

\section{Introduction to Monetary Remedies ${ }^{99}$}

Monetary remedies in intellectual property will be broken down among three categories: damages (Part IV) profits (Part V), and enhanced recoveries (Part VI). "Damages" has its ordinary meaning. "Profits" refers to the formerly equitable remedy of an accounting of defendant's profits resulting from an infringement. This remedy is to be distinguished from a plaintiff's lost profits, which may enter into the calculation of damages. "Enhanced recoveries" refers to the availability of triple damages in some patent and trademark settings (including enhanced profits for trademarks), to statutory damages that are optional in copyright, and to punitive damages that may be available in state unfair competition law.

95. King-Seeley Thermos Co. v Aladdin Industries, Inc., 321 F2d 577, 579 (2d Cir 1963) (additional restrictions also prescribed). 3).

96. See generally McCarthy, 2 Trademarks and Unfair Competition ch 26 at 281 et seq (cited in note

97. See, for example, Oral-B Labs, Inc. v Mi-Lor Corp., 810 F2d 20 (2d Cir 1987).

98. Restatement of the Law of Unfair Competition, Tentative Draft No 2, § 19 at 153 (Am L Inst, 1990).

99. A survey similar in scope to this one is Gary M. Ropski \& Marc S. Cooperman, Damages in USA Intellectual Property Litigation, 72 J Patent \& Trademark Office Society 179 (1990). The authors conclude that "[i]ntellectual property litigation is focussing more and more on monetary awards." Id at 211. Earlier surveys include Comment, Monetary Recovery under the Copyright, Patent, and Trademark Acts, 45 Tex L Rev 953 (1967) (authored by Paul H. Hubbard). 
All but the last of these remedies are authorized by the relevant major statutes, in settings that vary in their degree of detail. The major differences among copyright, patent, and trademark are the presence of a range of statutory damages in copyright, the absence of resort to defendant's profits in patent law, and the downplaying of damages in trademark cases. These, and some minor differences, will be expounded.

\section{DAMAges}

\section{A. Copyright}

Sometimes, but not often, a plaintiff's damages from an infringing act are crystal-clear. Harper $\mathcal{E}^{\circ}$ Row $v$. Nation Enterprises ${ }^{100}$ is such a truly rare case. When Nation "scooped" the publication of former President Ford's memoirs by publishing the most vivid parts about Nixon's resignation and pardon, Time magazine, which had paid in advance half of a $\$ 25,000$ contract with Harper for publishing similar excerpts, cancelled and refused to pay the remaining $\$ 12,500$. That amount was what Harper sued Nation for and won.

Ordinarily, the problem is to make a reasonable estimate of the plaintiff's sales captured by the infringer and the profits plaintiff would have made on those sales. Sometimes this inquiry is uncomplicated. Thus, in a 1970 Second Circuit case, ${ }^{101}$ the plaintiff produced a copyrighted lace design for one customer. That customer, Warner, persuaded defendant to copy the design more cheaply. As the court said, "it is plain that what Warner purchased from defendant, Warner would have bought from plaintiff had defendant not infringed." 102

Once adrift from such a tight identity between defendant's sales and plaintiff's lost sales, particularization of plaintiff's losses can become difficult. She must show that defendant's acts caused her lost sales. There may be other reasons for a falling-off; the bare fact of a decline from one year to the next need not be decisive. ${ }^{103}$ For example, the defendant may be reaching a somewhat different market. ${ }^{104}$

For an illustration of the difficulty of deciding damages in copyright infringements, one can turn to recent decisions that have put the Second and Seventh Circuits somewhat at odds. The Seventh Circuit case, Deltak, Inc. $v$. Advanced Systems, Inc. ${ }^{105}$ was an unusual one, aside from the copyright damages problems, in that the redoubtable Judge Posner, sitting as a district judge, found for the defendant-and was reversed by a panel of his colleagues on the court of appeals. The defendant had copied a substantial item from plaintiff's packet of computer program instruction materials. The item was

100. 471 US 539 (1985).

101. Thomas Wilson E Co. v Irving J. Dorfman Co., 433 F2d 409 (2d Cir 1990).

102. Id at 410 .

103. See Taylor v Meirick, 712 F2d 1112, 1120 (7th Cir 1983).

104. As in F.W. Woolworth Co. v Contemporary Arts, Inc., 344 US 228 (1952).

105. 767 F2d 357 (7th Cir 1985). 
not sold separately. Neither plaintiff's damages nor defendant's profits could be established, and the plaintiff was ineligible for statutory damages because its packet had not been registered. ${ }^{106}$ Under these circumstances, the court of appeals reached the conclusion that the value of use to the defendant could and should be determined, and such value would be plaintiff's recoverable damages. This actual value, the (non-existent) fee to which a willing buyer and a willing seller would have agreed, was left to be resolved by the trial court.

The facts in the Second Circuit case ${ }^{107}$ were remarkably similar, except that modest profits to the defendant were established and upheld. ${ }^{108}$ But Judge Winter for the court of appeals explicitly rejected Deltak's "value of use" approach as calling for an unrealistic "fictive" recreation of market value to the defendant of the wrongfully copied material. That this left the plaintiff almost empty-handed was the consequence of Congress's decision to deny statutory damages to authors who fail to make timely registration. Judge Winter drew support from the repudiation of Deltak by the Nimmer treatise. ${ }^{109}$ Professor Goldstein, however, thinks that Deltak is right. ${ }^{10}$ For what it is worth, so do $\mathbf{I}$, even though the Deltak approach is somewhat roundabout.

These two cases are challenging attempts to apply simple anodynes to hard cases. The simple anodynes are that damages are intended to compensate for the decline in market value of a copyright because of defendant's conduct, and that such declines can be measured by lost sales or by estimating reasonable royalties. ${ }^{11}$ Fortunately for plaintiffs, that these data can often be neither found nor estimated does not deter courts from trying. Damages do get awarded.

\section{B. Patents}

The same basic principle applies to patents as well as to copyrights. A plaintiff should be made whole for what she has lost because of defendant's infringement. There are significant differences in emphasis, however, two of which are laid down in the statute: damages must be "adequate," and in no event less than "a reasonable royalty for the use made of the invention by the infringer." 112 The search for a minimum reasonable royalty is combined with

106. See 17 USC $\$ 412$.

107. Business Trends Analysts, Inc. v Freedonia Group, Inc., 887 F2d 399 (2d Cir 1989).

108. Recoverable profits were found to be about $\$ 4,000$. The trial court (which was affirmed as to profits and reversed on damages) calculated damages of $\$ 50,000$. Id at 402 .

109. Id at 405, citing 3 Nimmer on Copyright $\$ 14.02$ at 14-16 through 14-17 (cited in note 3 ).

110. Goldstein, Copyright $\$ 12.1 .1$.1 at 181 (Supp 1991) (cited in note 3).

111. Reasonable royalty equivalents may be inferred from past licensing transactions. See Goldstein, 2 Copyright $\S 12.1 .1$ at $317-18$ (cited in note 3 ).

112. 35 USC $\$ 284$ (adequate damages must compensate plaintiff for "the value of what was taken"); Bandag, Inc. $v$ Gerrard Tire Co., 704 F2d 1578, 1582 (Fed Cir 1983). Two valuable recent works on the topic of section 284 are John M. Skenyon \& Frank P. Procelli, Patent Damages, $70 \mathrm{~J}$ Patent \& Trademark Office Society 762 (1988); and Ned L. Conley, An Economic Approach to Patent Damages, 15 Am Intell Prop L QJ 354 (1987). Consult also Peter B. Frank \& Michael J. Wagner, Computing Lost Profits and Reasonable Royalties, 15 Am Intell Prop L QJ at 391 (authors are accountants). 
diligent attention to plaintiff's lost profits as a proper measure of damages-a diligence enhanced by the unavailability of defendants' profits in patent remedies, a disparity that is underscored in Part V of this article.

A third area of emphasis is causation. In copyright, the defendant in his work has copied, distributed, performed, or publicly displayed an identified work of the plaintiff. In the technological world of patents, there may be competing patents, or there are often unpatented ways of doing the same thing. Similarly, in copyright law the defendant is free to use writings that are in the public domain; damages and injunctions should take account of this important privilege. 113 The patent owner must clear several hurdles. "To obtain as damages the profits [the patent owner] would have made absent the infringement," the owner must prove: "(1) demand for the patented product, (2) absence of acceptable noninfringing substitutes, ${ }^{114}$ (3) his manufacturing and marketing capability to exploit the demand, and (4) the amount of the profit he would have made." 115 The plaintiff in Panduit Corp. v. Stahlin Brothers Fibre Works did not establish lost profits, so the decision focused on reasonable royalties. Panduit is nevertheless regarded as the source of the four-element test for lost profits and is faithfully followed. 116

The apparent rigors of the four-fold test are softened by a light burden on the plaintiff: he need show only a "reasonable probability" of each element. ${ }^{117}$ Further, once the plaintiff has met his burden, the infringer has the burden of persuading an appellate court that the trial court miscalculated the lost profits. There are still other advantages for the patent owner. He may use an "incremental income" approach to calculate lost profits: if fixed costs have been covered by previous sales, they do not have to be accounted for in estimating profits on lost sales. Further, the "entire market value" rule allows the patentee to recover lost profits or royalties on unpatented components that normally would be sold with the patented machine. ${ }^{118}$

113. Courts often fail to recognize this fact. See Gary L. Francione, Facing the Nation: The Standards for Copyright, Infringement, and Fair Use of Factual Works, 134 U Pa L Rev 519 (1986).

114. Skenyon and Porcelli state that this is the most heavily litigated question in lost profit cases. See Skenyon \& Porcelli, J Patent \& Trademark Office Society at 779 (cited in note 112). There are several dimensions of this "but for" requirement that cannot be explored in this survey. See id at 779-83. One that favors the patentee and that has only very recently been recognized by the Federal Circuit is the idea that even if there are competing alternatives, the patentee is at least entitled to profits on a volume of sales equal to his existing share of the market. State Industries, Inc. $v$ Mor-Flo Industries, Inc., 883 F2d 1573 (Fed Cir 1989). See the 1991 update of Skenyon and Porcelli's article. John M. Porcelli \& Frank P. Skenyon, Patent Damages-Life in the 'But-For' World 1.50-1.61 (unpublished paper presented before the ABA section of Patent, Trademark and Copyright Law on Aug 12, 1991).

115. Panduit Corp. v Stahlin Bros. Fibre Works, 575 F2d 1152, 1156 (6th Cir 1978). Panduit is a powerful opinion by Judge Markey, Chief Judge of the Court of Customs and Patent Appeals and then of the Federal Circuit until 1991. In it he seems to be instructing his colleagues on the Sixth Circuit, with whom he was temporarily sitting, on many aspects of patent law.

116. See note 114 and the cases cited therein.

117. Kaufman Co., Inc. v Lantech, Inc., 926 F2d 1136, 1141 (Fed Cir 1991) (describing "reasonable probability" as an "objective test").

118. Skenyon \& Porcelli, $70 \mathrm{~J}$ Patent \& Trademark Office Society at 783-85 (cited in note 112). 
Finally, the patentee can argue that her profits would have been greater had it not been for "price erosion"- the free-riding infringer's depression of prices from the level that the patentee would have enjoyed had her legal monopoly not been impaired by the infringer's unlawful competition. ${ }^{119}$

Overall, proof of damages based on lost profits has been eased and expanded remarkably since the Federal Circuit came into being. The "reasonable royalty" assurance has likewise flowered. As recently as 1980 , the Third Circuit refused to recognize a reasonable royalty higher than a rate that had been established in several licenses, despite the patentee's persuasive argument that the rate he could collect had been driven down by the defendant's notorious infringement (though the court did allow the damages to be doubled). ${ }^{120}$

In finding a reasonable royalty, a trial court considers ffteen factors enumerated in an influential 1970 decision. ${ }^{121}$ The most problematic of these factors is the fifteenth, which dictates that, in the absence of an established royalty, the trier must construct the royalty rate to which a willing seller and a willing buyer would have agreed before the infringement commenced. In 1988, Judge Markey denounced this whole exercise as "fantasy," saying that such a calculation should at least be informed by experience. ${ }^{122}$

Here again, the benign ingenuity of the Federal Circuit has been at work developing a variety of devices that calculate "reasonable" royalties far beyond what any pre-infringement deal might have conceived.123 One especially significant development is the award of a combination of lost profits on that part of the market for which they plausibly can be calculated, with reasonable royalties on the remainder. ${ }^{124}$ Another pronounced advantage created for the patentee awards damages for the sales of many collateral non-

119. All of the advantages catalogued in the preceding two paragraphs are discussed in the Skenyon \& Procelli articles (cited in notes 112 and 114). An opinion that deals with several of them is Paper Converting Machine Co. v Magna-Graphics, 745 F2d 11 (Fed Cir 1984). The most celebrated damages award of modern times (\$909.5 million) is Polaroid Corp. $v$ Eastman Kodak Co., 16 USPQ 2d 1481 (D Mass 1990). There the defendant argued unsuccessfully that its (infringing) entry had expanded the total market for instant camera and that accordingly Polaroid's damages were lessened. Id at 1495-98.

120. Trio Process Corp. $v$ L. Goldstein's Sons, Inc., 612 F2d 1353 (3d Cir 1980). In this case, the plaintiff endured fourteen years of litigation and four trips to the court of appeals!

121. Georgia-Pacific Corp. v U.S. Plywood-Champion Papers, Inc., 318 F Supp 1116, 1120 (SDNY 1970), modified on different grounds and aff'd 446 F2d 295 (2d Cir 1971).

122. Fromson $v$ Western Litho. Plate $\mathcal{E}$ Supply Co., 853 F2d 1568, 1575 (Fed Cir 1988). The importance of attending to experience was declared by the Supreme Court in Sinclair Refining Co. $v$ Jenkins Petroleum Co., 289 US 689, 698 (1933). Conley, 15 Am Intell Prop L QJ at 377 (cited in note 112), still contends the search for a rate that "would have been" reached is a "real-world approach," in contrast to an "analytic" approach advocated by Skenyon and Porcelli, $70 \mathrm{~J}$ Patent \& Trademark Office Society at 398 (cited in note 112).

123. For examples, see Porcelli \& Skenyon, Patent Damages-Life in the 'But-For' World at 1.16 (cited in note 114).

124. See id at 1.5; Skenyon \& Porcelli, $70 \mathrm{~J}$ Patent \& Trademark Office Society at 784 (cited in note 112 ). 
patented items that ordinarily would follow the sale of a patented item (for example, sales of eyeglasses accompanying a patented display case). ${ }^{125}$

All in all, the lower courts, egged on by the Federal Circuit, ${ }^{126}$ are heeding Judge Markey's wry observation in Panduit that " $[t]$ he infringer would have nothing to lose and everything to gain if he could count on paying only the normal, routine royalty non-infringers could pay." 127 For example, the court in Stickle held that "the trial court may award an amount of damages greater than the reasonable royalty so that the award is adequate to compensate for the infringement."'128

Finally, a word about pre-judgment interest is warranted. Section 284, alone among the three statutes on which this survey is based, ${ }^{129}$ directs the award of "interest and costs as fixed by the court."130 In General Motors Corp. v. Devex Corp. , $^{131}$ the Supreme Court, after noting that the phrase " "fixed by the court' . . . leaves the court some discretion," held that "prejudgment interest should be awarded under section 284 absent some justification for withholding such an award."132 This pronouncement has resulted in routine awards of prejudgment interest, according to Porcelli and Skenyon. ${ }^{133}$ They point out that patent cases can be extremely protracted, so that "prejudgment interest can easily equal or exceed the basic damages award." 134

The absence of any general provision for prejudgment interest in the copyright and trademark statutes is matched only by the complete silence of the standard treatises and a bare whisper from case law. Two courts of appeals have recently reached contrary outcomes in copyright cases. ${ }^{135}$ Judge Posner, for a Seventh Circuit panel, not only endorsed an award of prejudgment interest against a flagrant trademark infringer, but went on "to generalize, and to announce a rule that prejudgment interest should be presumptively available to victims of federal law violations."'136 Professor Dobbs, reviewing the topic at large, apart from statutory directions or silences, reports "a continued state of uncertainty and even irrationality."137

125. Trans-World Mfg. Corp. v Al Nyman E Sons, Inc., 750 F2d 1552, 1568 (Fed Cir 1984). See Skenyon \& Porcelli, $70 \mathrm{~J}$ Patent Trademark Office Society at 770 (cited in note 112). This "convoy effect" is very like the "entire market value" rule mentioned at text accompanying note 119.

126. See, for example, Sickle v Heublein, Inc., 716 F2d 1550, 1561-62 (Fed Cir 1983).

127. Panduit, 575 F2d at 1158.

128. Sickle, 716 F2d at 1563 (emphasis added).

129. But with respect to counterfeit trademarks, the court is given discretion to award prejudgment interest. $15 \mathrm{USC} \$ 1117(\mathrm{~b})$.

130. 35 USC $\$ 284$.

131. 461 US 648 (1983).

132. Id at 656-57.

133. Porcelli \& Skenyon, Patent Damages-Life in the 'But-For' World at 1.76 (cited in note 114)

134. Id. An example is Devex, 461 US at 651 , where damages were almost $\$ 9$ million, while interest came to $\$ 11$ million. The case, concluded in 1983 , began in 1956 !

135. Compare Robert R. Jones Associates, Inc. $v$ Nino Homes, 858 F2d 274 (6th Cir 1988) (interest award vacated), with Frank Music Corp. v Metro-Goldwin-Mayer, Inc., 886 F2d 1545 (9th Cir 1989) (Copyright Act of 1909 allows award of interest).

136. Gorenstein Enterprises, Inc. v Quality Care-USA, Inc, 874 F2d 431, 436 (7th Cir 1989). A concurring judge parted company with the dictum, believing that prejudgment interest was a matter of discretion. Id at 438-39 (Ripple concurring).

137. Dan B. Dobbs, Handbook on the Law of Remedies $\S 3.5$ at 173 (West, 1973). 


\section{Trademarks}

Damages are said to play a subordinate role in trademark disputes, chiefly because the plaintiff need establish only the likelihood of confusion in order to win the primary remedy of an injunction. If the plaintiff cannot show any actual confusion, ordinarily she cannot prove any damages. ${ }^{138}$ Once the plaintiff can demonstrate actual confusion and lost sales, or injury to reputation, damages are available. ${ }^{139}$

The prevalence of franchising trademarks opens the door to a reasonable royalty approach to damages; that is, what the plaintiff usually charges for the use of its name. Fortunately, this royalty approach is nowhere near as common nor as complicated as that utilized in patent law. ${ }^{140}$

One form of damages is unique to trademark and unfair competition law: the occasional practice of requiring defendants to pay for corrective advertising. The leading case on this remedy is not a trademark case at all. ${ }^{141}$ It arose from a massive misleading advertising campaign directed at running down U-Haul, the dominant truck and trailer rental company. Jartran sought a share of that market, and indulged in tactics that left it at the wrong end of a $\$ 40$ million "damages" judgment. ${ }^{142}$ More closely linked to a trademark is the well-known "reverse confusion" case of Big $O$ Tire Dealers $v$. Goodyear Tire E' Rubber Co., ${ }^{143}$ where the large defendant massively appropriated the small plaintiff's "Bigfoot" trademark for tires. The damages, as revised by the court of appeals, included $\$ 678,302$ in lieu of corrective advertising. ${ }^{144}$

These cases, like trademark monetary remedy cases generally, are suffused with equitable considerations. Preoccupation with equity is doubtless influenced by the sequence of section 35 of the trademark statute, which states that a successful plaintiff "shall be entitled . . . subject to the principles of equity, to recover (1) defendant's profits, (2) any damages sustained by the plaintiff, and (3) the costs of the action."145 Thus, all elements of monetary recovery in trademark cases are under the influence of equity.

138. Champion Spark Plug Co. v Sanders, 331 US 125, 128-30 (1947). See generally, McCarthy, 2 Trademarks and Unfair Competition $\S 30: 28$ at 514-17 (cited in note 3). The statutes in about half the states that penalize trademark dilution authorize injunctive relief only. See, for example, Mass Ann Laws ch 110B, § 13 (Michie/Law Co-op 1985).

139. See Story Parchment Co. v Paterson Parchment Paper Co., 282 US 555, 563 (1931) (proof of some damage permits considerable leeway in estimating the amount of damage).

140. And it is subject to the same criticism that is levelled in patent law-that a going royalty rate does not sufficiently deter or punish an intentional infringer. See McCarthy, 2 Trademarks and Unfair Competition $\$ 30: 27(\mathrm{D})$ at $512-13$ (cited in note 3).

141. U-Haul International, Inc. v Jartran, Inc., 793 F2d 1034 (9th Cir 1986). See also Arthur Best, Monetary Damages for False Advertising, 49 U Pitt L Rev 1 (1987).

142. U-Haul, $793 \mathrm{~F} 2 \mathrm{~d}$ at 1037.

143. 561 F2d 1365 (10th Cir 1977).

144. Id at 1375 .

145. 35 USC $\$ 1117$ (a) (emphasis supplied). 


\section{Profits}

\section{A. Copyright}

The primary aim of damages awards in copyright cases is to transfer to the copyright owner all or part of the profits that a defendant has gained by infringing. Though the origin of this remedy lies in the restitutionary tendencies of courts of equity, the foundation is (and has been since 1909) statutory, specifically section $504(\mathrm{~b})$, which states:

The copyright owner is entitled to recover the actual damages suffered by him or her as a result of the infringement, and any profits of the infringer that are attributable to the infringement and are not taken into account in computing the actual damages. In establishing the infringer's profits, the copyright owner is required to present proof only of the infringer's gross revenue, and the infringer is required to prove his or her deductible expenses and the elements of profit attributable to factors other than the copyrighted work. ${ }^{146}$

No mention is made of equity. Defendant's profits are routinely recoverable.

Three problems recur with awards of profits: (1) establishing the expenses that are properly deductible from the infringer's gross revenue; (2) apportioning the "elements of profit attributable to factors other than the [infringed] copyrighted work"; and (3) once profits are established, avoiding improper cumulation with plaintiff's actual damages.

Deriving net profits from gross receipts leads to several sub-problems with allocating expenses. Fortunately, most of these are soluble via standard practices in cost accounting, and need not detain us here. ${ }^{147}$ It is, however, appropriate to observe that the burden of establishing expenses falls entirely on the defendant. When the defendant cannot or will not prove expenses, extraordinary windfalls can occur. The extreme instance is Blackman v. Hustler Magazine, Inc., ${ }^{148}$ in which the plaintiff offered to sell nude photographs of a fleetingly notorious woman to the magazine for $\$ 35,000$. The perennially notorious Larry Flynt simply misappropriated the pictures, exploited them widely, and then claimed that Hustler's books had been lost. In the end, this frivolity cost Flynt almost $\$ 2$ million.

Once total profits have been calculated, the trier must decide what else, aside from the infringed work, contributed to those profits. The classic case, (which also settled that an apportionment is appropriate) is Sheldon v. MetroGoldwyn Pictures Corp. ${ }^{149}$ In Sheldon, the Supreme Court affirmed an award of 20 percent of the profits from a motion picture to the authors of a play from

146. 17 USC $\S 504(b)$

147. See 3 Nimmer on Copyright $\$ 14.03$ at $14-23$ through $14-38$ (cited in note 3 ). One major element of expense that continues to be contentious is the deductibility of income taxes paid on accountable profits. Courts inject an appraisal of defendant's conduct; if the infringement was "conscious and deliberate," credit for income taxes may be denied. Larson Co. v Wrigley Co., 277 US 97, 99 (1928). Compare Love v Kitny, 2 Copyright L Rptr (CCH) I 26, 789 (SDNY 1991) (credit denied also when infringement non-willful, on ground that, since infringer's profits paid to plaintiff will be deductible by defendant, there will be no taxable income on that amount).

148. 800 F2d 1160 (DC Cir 1986).

149. 309 US 390 (1939). 
which too much of the film was derived. Courts often say that they err on the side of generosity to the prevailing plaintiff. Only approximations are possible in most cases. ${ }^{150}$ Under the statute, the infringer has the burden of establishing what the apportionment should be.

Despite concerns that plaintiffs were receiving windfalls, cases construing the 1909 Copyright Act ${ }^{151}$ became quite indulgent in allowing plaintiffs to recover both their lost profits and the defendant's profits. This trend, most marked in the Second Circuit, ${ }^{152}$ arose in part because of some rather loose language in the 1909 statute, which directed the infringer to pay, beyond actual damages, "all the profits which the infringer shall have made"153_rather ignoring the next three words, "from such infringement." 154 The 1976 statute attempted to curb immoderate cumulation by allowing "any profits ... that are attributable to the infringement and are not taken into account in computing the actual damages." 155 There are endless divergences that can develop between the plaintiff's supposed damages and the defendant's profits. The straightforward way to approach such a problem requires taking whatever steps are necessary to establish actual damages, then determining whether defendant's profits, properly apportioned, exceed plaintiff's damages. Plaintiff is then entitled to the larger amount. Judge Posner followed essentially this approach in a leading post-1976 decision on avoiding improper cumulation. ${ }^{156}$

\section{B. Patents}

In striking contrast to the routine recognition of defendants' profits in copyright law, the patent statute makes no provision for such awards.

For a long time prior to 1946 , patentees could recover both damages and profits. The predecessor to section 284 listed profits first: "in addition to the profits to be accounted for by the defendant, the damages the complainant has sustained . . ."157 Suddenly, in 1946,158 all references to profits were eliminated and the statute acquired substantially its present content. ${ }^{159}$

Congress' intent has not become clearer with time. The brief committee report that accompanied the 1946 change stressed the complexity of accountings of profits. It also added a cryptic throwaway line: "[T]he bill

150. A beguiling recent example is Sygma Photo News, Inc v High Society Magazine, Inc., 778 F2d 89, 94-96 (2d Cir 1985), where the court had to decide how much an infringing nude photograph of Raquel Welch contributed to the profits of a "skin" magazine cover. Faced with estimates of $20 \%$ and $75 \%$, the court settled on $50 \%$.

151. Copyright Act of 1909,35 Stat 1075, superseded by 17 USC $\$ 8101$ et seq (1988).

152. See especially Thomas Wilson $\xi$ Co. v Irving J. Dorfman Co., 433 F2d 409 (2d Cir 1970).

153. Copyright Act of $1909 \S 25$ (b), 35 Stat at 1081 (emphasis added).

154. Id.

155. 17 USC $\$ 504$ (b).

156. Taylor $v$ Meirick, 712 F2d 1112, 1119-21 (7th Cir 1983); compare Abeshouse v Uliragraphics, Inc., 754 F2d 467 (2d Cir 1985). Cumulation is not permissible in trademark cases. Century Distilling Co. $v$ Continental Distilling Corp., 205 F2d 140, 149 (3d Cir 1953).

157. Act of July 8 th, $1870 \S 55,16$ Stat 206 .

158. Act of August 1, 1946, 60 Stat 778 .

159. Though it was substantially recast in the Patent Act of 1952, 66 Stat 792. 
would not preclude the recovery of profits as an element of general damages." 160

In 1964, the Supreme Court weighed in rather heavy-handedly, flatly declaring that " $[t]$ he purpose of the change was precisely to eliminate the recovery of profits as such and allow recovery of damages only." 161 This assertion came in the second round of Aro Manufacturing Co. v. Convertible Top Replacement Co., ${ }^{162}$ a battered landmark of contributory infringement that had little to do with the availability of profits. Furthermore, Justice Brennan made this pronouncement in a section of his opinion that had the support of only four justices. Justice Harlan abstained as to that part. The four dissenters, however, had nothing whatever to say about profits. They were not in favor of awarding anything to the plaintiff.

The plurality's discussion in Aro, whatever its proper weight, caused the lower courts to fall into line. ${ }^{163}$ The Supreme Court again spoke in 1983, citing Aro for a passing observation that "[i]n 1946 Congress excluded consideration of the infringer's gain by eliminating the recovery of profits." 164

Only the irrepressible Judge Rich has gone against the current. In a 1985 decision for a panel of the Federal Circuit, he held that evidence of defendants' profits continues to be relevant in calculating a reasonable royalty, or as a reasonable approximation "of the patent owner's lost profits." 165 The case, to be sure, was one where plaintiff and defendant were alone in the "marsh buggy" market and there were no complicating elements such as unpatented components.

A final oddity of this aberration in remedies jurisprudence is that defendants' profits are still recoverable for infringement of a design patent. ${ }^{166}$ Is this simply an oversight, or does it reflect the proximity of design patent to copyright?

\section{Trademarks}

One would expect an accounting of profits to be routinely available in trademark cases. The Lanham Act, after all, is similar to the patent statute before the 1946 amputation of profits in that profits are mentioned before damages. ${ }^{167}$ Yet the rhetoric, and apparently the practice, is quite different.

160. HR Rep No 1587, 79th Cong, 2d Sess 2 (1946), cited in Chisum, 5 Patents $\$ 20.02$ at 20-60.1 (cited in note 3).

161. 377 US 476, 505 (1964).

162. The original round was Aro Manufacturing Co. v Convertible Top Replacement Co., 365 US 336 (1961).

163. See Chisum, 5 Patents $\$ 20.02[4]$ at 20-58 through 20-70 (cited in note 3).

164. General Motors Corp. v Devex, 461 US 648, 654 (1983).

165. Kori Corp. $v$ Wilco Marsh Buggies Eं Draglines, 761 F2d 649, 655 (Fed Cir 1985) (also explaining the 1946 elimination of profits from the statute). See also Slimfold Mfg. Co. v Kinkead Industries, Inc., 932 F2d 1453, 1458 (Fed Cir 1991) (Judge Rich writes that an assertedly low royalty award "was not the only damages which the district court awarded; the district court also awarded all profits that Kinkead realized in the form of manufacturing cost savings.").

166. 35 USC $\S 289$ (1988) ([T]he infringer "shall be liable to the owner to the extent of his total profit but not less than $\$ 250 \ldots .$. .").

167. See 15 USC $\S 1117(\mathrm{a})$. 
An award of profits is generally said to require a finding that the infringement was "deliberate," "willful," or in "bad faith." 168

McCarthy neatly characterizes these hurdles to an award of profits by saying that " $[t]$ he courts appear not willing to grant an accounting of profits unless the judge 'gets mad' at the defendant."169 Judges do seem to "get mad" rather frequently. Where the infringement was short-lived, howeveras in Reader's Digest Assoc. Inc. v. Conservative Digest, Inc. ${ }^{170}$ where defendant's excessive imitation of the appearance of Reader's Digest's cover occurred for only two issues-no profits are awarded. It does appear that the courts, in searching for "bad" behavior before they will award profits, are influenced by the statute's invocation of "principles of equity," a constraint no longer found in the copyright statute.

Although the equitable elements seem to impel courts to search for "bad faith" and other pejoratives, once these have been found, equity assists the plaintiff. Damages are not available in trademark cases unless the plaintiff can prove some injury, which she often cannot do. No time is proof of damage more difficult than when the plaintiff desires to stop the use of her mark on non-competing goods. Familiar trademark law may allow a plaintiff to enjoin such use, depending on an array of factors. ${ }^{171}$ In an increasing number of cases, she may also get an accounting of profits. These measures are justified by the concept of unjust enrichment, invoked "subject to the principles of equity." 172 A leading case is emphatic that "[t]he dollar amount of the recovery in an accounting for profits under the unjust enrichment rationale has no relation to the damages, if any, sustained by the plaintiff in the action." 173 Deterrence of further infringement is another rationale.

As in calculations of profits by copyright infringers, the defendant may deduct certain expenses to establish net profits. The court must allow the defendant to attempt to apportion any profits between those attributable to the infringement and those allocable, for example, to the "goodness" of his goods. ${ }^{174}$ A recent vivid example of a generous allocation of profits in a case where the trial court found no actual damages, nor any reason to levy a reasonable royalty nor to require corrective advertising, is Sands, Taylor $\mathcal{E}^{\circ}$

168. McCarthy, 2 Trademarks and Unfair Competition $\S 30: 25$ at 498 (cited in note 3). Compare Roulo $v$ Russ Berrie, 886 F2d 931, 941 (7th Cir 1989) (stating that "[t]here is no express requirement ... that the infringer wilfully infringe the trade dress to justify an award of profits"). But the court in Roulo still emphasized "principles of equity" and "equitable considerations." Id. Roulo is of unusual interest because the court found both copyright and trade dress infringement. Yet the discussion of monetary remedies dwelt entirely on Lanham Act cases.

169. McCarthy, 2 Trademarks and Unfair Competition $\$ 30: 25$ at 498 (cited in note 3).

170. 831 F2d 800 (DC Cir 1987). This was another instance like Roulo, 886 F2d 931, where, although the same activity constituted both copyright and trade dress infringement, the remedy discussion was entirely directed to the Lanham Act.

171. ALI Restatement $\$ 21$ at $187-88$ (cited in note 39 ).

172. 15 USC $\$ 1117(\mathrm{a})$.

173. Maier Brewing Co. v Fleishmann Distilling Corp.. 390 F2d 117, 124 (9th Cir 1968); see also Monsanto Chemical Co. v Perfect Fit Products Mfg. Co., 349 F2d 389, $391-92$ (2d Cir 1965); contra, see McCarthy, 2 Trademarks and Unfair Competition $\S 30: 25$ at $504 \mathrm{nl} 6$ (cited in note 3).

174. See Gilson, Trademark Protection and Practice $\$ 8.08[3]$ at 8-16 (cited in note 3). 
Wood v. Quaker Oats Co. ${ }^{175}$ Quaker Oats, the manufacturer of Gatorade, made heavy deliberate use of plaintiff's registered mark, "Thirst Aid," in advertising that "Gatorade is Thirst Aid." Plaintiff was using the mark modestly at the institutional level "on ice cream toppings." 176 The trial court decided that 10 percent of Gatorade's pre-tax profits were attributable to the infringing slogan, and awarded the plaintiff $\$ 24.7$ million "to prevent defendant's unjust enrichment." 177

This brief sketch of recovery of profits in trademark cases may convey a misleading impression that some degree of clarity exists in the cases. The most penetrating examination of the topic speaks of the "hodgepodge and confusion of judge-made rules of recovery," and especially condemns accounting for profits as a "common law dinosaur surviving more by tradition than utility."178

\section{VI \\ ENHANCED RECOVERY}

\section{A. Copyright}

The copyright scheme of statutory damages ${ }^{179}$ - which specifies a range of civil penalties payable to a prevailing plaintiff, not to the government-is probably unique. ${ }^{180}$

The present schedule is a simplified version of that in the $1909 \mathrm{Act}$, the origins of which can be traced, in part, back to $1831 .^{181}$ The $1909 \mathrm{Act}$, in an elaborate schedule, included such oddities as $\$ 50$ for every infringing delivery of a lecture, sermon, or address. But these amounts were not mandatory; they were inserted merely as "an aid to the court in awarding such damages "as shall appear to be just'182" within a minimum of $\$ 250$ and a maximum of $\$ 5000$. The floor and ceiling were only recently raised to $\$ 500$ and $\$ 20,000$, in recognition of inflation, and as an incentive to register works in the Copyright Office. ${ }^{183}$

175. 18 USPQ 2d 1457 (ND Ill 1991).

176. Id at 1463 .

177. Id at 1474. With interest and fees, the judgment (the largest ever, and now on appeal) came to $\$ 42.6$ million.

178. James M. Koelemay, Jr., Monetary Relief for Trademark Infringement under the Lanham Act, 72 Trademark Rptr 458, 525, 537 (1982).

179. 17 USC $\$ 504$ (c).

180. For example, there are liquidated damages provisions in the Fair Labor Standards Act, 29 USC $\$ 216$ (b) (1988), carried over into the Age Discrimination in Employment Act, 29 USC $\$$ 636(b) (1988), which offer liquidated damages in addition and equal in amount to actual damages for lost back pay in cases of willful violations. See Thurston $v$ Trans World Airlines, Inc., 469 US 111, 125-28 (1985). But they do not have the flexibility in application and amount that the copyright provisions do.

181. See generally, William S. Strauss, The Damage Provisions of the Copyright Law, in The Copyright Society of the USA, Studies on Copyright 995, 1003-07 (Rothman/Bobbs-Merrill, 1963).

182. Jewell-LaSalle Realty Co. v Buck, 283 US 202, 207 (1931).

183. Statutory damages are unavailable unless timely registration is accomplished. 17 USC $\$ 412(2)$. The recent increases came in the Berne Convention Implementation Act of 1988, Pub L No $100-568,102$ Stat $2853 \S 10$ (b). 
In the past, much attention was paid to minimum damages because of their usefulness as a weapon for movie distributors pursuing unlicensed exhibitors and to music publishers trying to police public performances without licenses from ASCAP or BMI. ${ }^{184}$ Movie exhibitors, now fewer in number, seem to have become more law-abiding. A steady trickle of reported cases continues, however, against taverns, retail stores, and juke-box operators without licenses to perform copyrighted music. In addition, recalcitrant non-licensees continue to try to defend themselves-almost always without success. ${ }^{185}$

The most striking change in the 1976 general revision was to shift the power to choose statutory damages from the court to the copyright owner. The next major innovation offered an opportunity for the copyright owner who so elected to prove that the infringement "was committed willfully." Then the court in its discretion may award up to $\$ 100,000$ (doubled from $\$ 50,000$ in 1988$) .186$

Damages for willful infringement are a powerful tool for a plaintiff who might have difficulty proving either actual damages or defendant's profits. Two problems recur in definition and administration. First, what is "willfulness"? The prevailing test, inspired by the Nimmer treatise, ${ }^{187}$ assumes willfulness from a finding that the defendant knows that the work she is copying is protected. ${ }^{188}$ In a typical violation of musical performance rights, the infringer will have been warned that she should have a license; thus, willfulness is indisputable. When the facts are less clear-cut, the obligation to establish a defendant's subjective knowledge may tempt the trier and the plaintiff to apply a less exacting standard, such as presumed knowledge, or a "should have known" test. ${ }^{189}$ This temptation should be

184. See generally Ralph S. Brown, The Operation of the Damage Provisions of the Copyright Law: An Exploratory Study ("Exploratory Study"), in Copyright Society of USA, ed, 2 Studies on Copyright at 1067, 1078-82 (cited in note 10 ).

185. A rare recent exception is found in a decision that interpreted, in favor of a large chain of small retail stores, the provision in 17 USC $\$ 110(5)$ that allows the use of "home-style" receivers in business establishments. Edison Brothers Stores v Broadcast Music Inc., 954 F 2d 1419 (8th Cir 1992); see also Broadcast Music, Inc., v Claire's Boutiques, Inc., 949 F2d 1482 (7th Cir 1991).

The stores in both cases persuaded the triers and the courts of appeals that the number of stores was not as significant as their small size in bringing them within the statutory exemption, which was tailored to the facts in Twentieth Century Music Corp. $v$ Aiken, 422 US 151 (1975) (receipt of copyrighted songs on radio of small business establishment held not an unlicensed performance).

186. Berne Implementation Act of $1988 \S 10(\mathrm{~b}), 102$ Stat at 2860. In the 1909 Act the forerunner of "committed willfully," was "after actual notice," and there was no ceiling. 35 Stat 1075. But until recently there were few reported instances of awards in excess of $\$ 5,000$. See Brown, Exploratory Study at 1085 (cited in note 184). However, things have changed since 1958. See, for example, Sid $\xi$ Marty Kroff Television Productions, Inc. $v$ McDonald's Corp., 221 USPQ 114 (CD Cal 1983) (\$1,044,000); Kamar Intl v Russ Berrie E Co., Inc., 829 F2d 783 (9th Cir 1987) (award of $\$ 460,000$ which represented $400 \%$ of defendant's gross profits). Both cases were governed by the 1909 statute.

187. 3 Nimmer on Copyright $\$ 14.04[\mathrm{~B}][3]$ at $14-48$ through 14-49 (cited in note 3 ).

188. See, for example, RCA/Ariola Intl, Inc. v Thomas E Graystone Co., 845 F2d 773 (8th Cir 1988) (tape-to-tape record copying; willfulness not found despite incriminating circumstances).

189. See, for example, Video Views, Inc. v Studio 21, Ltd., 925 F2d 1010 (7th Cir 1991) (includes, among other things, an interesting discussion of willfulness, but in a situation where the trial judge set aside a jury verdict of willfulness as unsupported by evidence. Accordingly, the following statement, in support of a "reckless disregard" or "should have known" standard, vivid though it is, 
resisted. The infringer will not escape liability if willfulness is not found; she remains liable for regular statutory damages of $\$ 500$ to $\$ 20,000$ or for actual damages and profits. ${ }^{190}$

The second problem is the calculation of statutory damages, which is required whether or not willfulness is found. The statute provides no guidance; the court can guess what actual damages or profits might have been. If an award is increased for willfulness, it is considered appropriate to consider deterrence, especially since the possibility of enhanced statutory damages is said to preclude the award of additional punitive damages. ${ }^{191}$ For example, performing rights collection agencies ordinarily may be content to recover the equivalent of lost license fees. In a recent case, ${ }^{192}$ where a club owner was extraordinarily recalcitrant, however (he would not take a license from ASCAP, though he had one from BMI), the court awarded $\$ 40,000$ plus attorney's fees of about the same magnitude, which the court said was three times the evaded license fees ${ }^{193}$-an obvious echo of the triple damages that are sometimes available in patent and trademark cases.

Copyright liability is strict liability. The only provisions that assist innocent infringers ${ }^{194}$ are found in the statutory damages section. They provide for a reduction of minimum damages from $\$ 500$ to $\$ 200$ per infringement if the infringer "was not aware and had no reason to believe that his or her acts constituted an infringement."195 Further, academic and public broadcasting institutions can escape statutory damages altogether if they or their employees believed that their infringements were fair use. This exemption mollified educators who wanted a broad fair use exemption for their copying. There is little reported application of these diminished damages.

Finally, many issues concerning multiple infringements were not resolved or were imperfectly resolved by the 1909 Act. For example, if 200 network stations broadcast a song without permission, it was unclear whether that constituted one or 200 infringements. ${ }^{196}$ The present act, with apparent

probably counts as dictum: "[O]ne who undertakes a course of infringing conduct may neither sneer in the face of the copyright owner nor hide its head in the sand like an ostrich." Id at 1021.

Video Views is also the latest statement on the controverted issue of a right to jury trial when the plaintiff seeks only statutory damages. The court held that, even though the trial judge decides the amount of statutory damages, there is a constitutional right to a jury trial on the questions of infringement and willfulness. Id at 1016. See generally Brown \& Denicola, eds, Cases on Copyright at 432 (cited in note 60 ).

190. One commentator would go a little beyond requiring "actual knowledge." See Note, Willful Copyright Infringement: In Search of a Standard, 65 Wash L Rev 903, 914-19 (1990) (authored by Jeffrey M. Thomas) (A demonstration of likely knowledge of adverse rights would impose on the defendant a burden of showing that she made further investigation of the plaintiff's rights and reasonably concluded that she was not infringing.). This proposal derives from patent law.

191. 3 Nimmer on Copyright $\$ 14.02[B]$ at $14-19$ (cited in note 3 ).

192. Chi-Boy Music v Charlie Club, Inc., 930 F2d 1224 (7th Cir 1991).

193. Id at 1229-30.

194. Aside from people misled by omission of notice during the period January 1,1978 to March 1,1989 , after which notice became optional. See 17 USC $\$ 405(b)$.

195. Id $\S 504(\mathrm{c})(2)$.

196. 200, according to Law v National Broadcasting Co., 51 F Supp 798, 799 (SDNY 1943). 
clarity, states that the $\$ 500$ minimum and $\$ 20,000$ maximum apply "to all infringements involved in the action with respect to any one work." 197 Thus, if the network performed the song on 200 stations and on 200 occasions, it would appear to be liable for only one infringement. This austerity has created its own difficulties and complaints, which the treatises and commentators cover quite adequately. ${ }^{198}$

\section{B. Patents}

Both the patent and the trademark statutes use the same vehicle for enhanced recoveries: judicial discretion to increase damages up to three times the amount of actual damages found. ${ }^{199}$ There is, however, enough variation of approach in the two fields to warrant separate discussion. Furthermore, while recovery of defendants' profits is excluded from the patent statute, the Lanham Act's damages section has an odd provision that authorizes the court either to increase or decrease profits "as the court shall find to be just."200

The level of conduct that is said to justify enhancing patent damages is the same "willfulness" mentioned above in copyright. ${ }^{201}$ "Bad faith" is equally emphasized. Two policy considerations must be balanced: on the one hand, infringement should be deterred; on the other, there is a public interest in allowing competitors to test the validity of patents. ${ }^{202}$ Accordingly, courts routinely recite that " $[\mathrm{a}] \mathrm{n}$ increase in damages for willfulness . . . is generally inappropriate when the infringer mounts a good faith and substantial challenge to the existence of infringement."203 The profusion of litigation is perhaps sufficient testimony to the uncertainties that attend inquiries into the good faith of challenges both to validity and to infringement. ${ }^{204}$ Accordingly, the putative infringer must proceed with some caution; the orthodox way of avoiding "bad faith" is to seek an opinion from a competent patent attorney that a patent you wish to ignore is not valid, or, if it is, that what you propose to do does not infringe. ${ }^{205}$

197. 17 USC $\$ 504(c)(1)$.

198. See Goldstein, 2 Copyright $\$ 12.2 .2$ at 342-51 (cited in note 3); 3 Nimmer on Copyright $\S 14.04[D]$ at 14.55 (cited in note 3). Consider also Wall Disney Co. v Powell, 897 F2d 565, 569-70 (DC Cir 1990) (six different poses of Mickey and Minnie Mouse on T-shirts constituted only two infringements, not twelve as the trial court found). An able student note is critical of this opinion. See Statutory Damages for the Multiple Infringement of a Copyrighted Work, 6 Cardozo Arts \& Enter L J 463 (1988) (authored by Peter Thea).

199. 35 USC $\S 284$ (patents); 15 USC $\$ 1117$ (b) (trademarks).

200. 15 USC $\$ 1117(\mathrm{a})$.

201. But note that the statute itself gives no guidance whatever to the court.

202. Lear, Inc. v Atkins, 395 US 653, 670-71 (1969).

203. Paper Converting Machine Co. v Magna-Graphics, 745 F2d 11, 20 (Fed Cir 1984).

204. See Chisum, 5 Patents $\S 20.03[4][b]$ at 20-179.3 (cited in note 3 ).

205. Id $\S 20.03[b][i v],[v]$ at 20-180ff. To the skeptical outsider (including the author), the attention that courts in patent cases give to the opinions of counsel is almost touching. They are appraised within "the totality of circumstances," which is a ubiquitous phrase. See, for example, cases cited in id $\S 20.03[4]$ at 20-185. Reliance on the opinions of counsel rarely surface in other intellectual property cases. In patent law, there appears to be a benign full employment program for 
Also relevant to increased damages are the circumstances that will permit a finding that the defendant was excusably ignorant of the existence of the threatening patent. Relevant to this excuse-which may be effective-is the patent statute's position on marking patented articles. Unless the familiar "Patent" or "Pat." followed by the patent number is properly attached, no damages, ordinary or enhanced, can be had except for in cases of infringements occurring after the patentee has begun affixing proper notices or the infringer had actual notice of the claimed infringement. ${ }^{206}$

Once the patentee has vaulted all these hurdles, the amount of increased damages seems to repose largely in the discretion of the trial judge. Reported outcomes range from one-quarter through double damages to the maximum of triple damages ${ }^{207}$-accompanied, "in exceptional cases," by "reasonable attorney fees."'208

\section{Trademarks}

Exercise of the discretion to increase trademark damages may be inhibited by the relatively high threshold for monetary awards generally found in trademark law. But if a plaintiff has established the existence of damages, and can further persuade the trier that the infringement was willful and in bad faith, the trial court may award up to triple damages. Similarly, the court has discretion to increase or, uniquely, to decrease an award of defendant's profits. This clause is also unique in that there is no stated ceiling on a particular increase of profits. However, the profits adjustment clause has rarely been used, and its limits have not been tested. If it is already true, as McCarthy suggests, that profits in trademark cases are awarded only if the judge is "mad at" the defendant, ${ }^{209}$ it would seem to require truly outrageous conduct to justify magnifying profits. Reducing profits can be a roundabout way of accounting for profits not resulting from the infringement ${ }^{210}$ or, more appropriately, for an equitable judgment that all of a defendant's large profits would unjustly enrich the plaintiff. 211

Overhanging both damages and profits enhancement is the penultimate admonition of section 35 that "[s]uch sum in either of the above circumstances shall constitute compensation and not a penalty."'212 Read as an admonition, the clause is troublesome. How can tripling actual damages

patent lawyers, aimed only at avoiding enhanced damages. The numerous decisions staking out the limits of reliance on such opinions deserve anthropological exploration, but not in this article.

206. 35 USC § 287; see also Chisum, 5 Patents $\$ 20.03$ [7][c] at 20-249 through 20-266.8 (cited in note 3 ).

207. Chisum, 5 Patents $\$ 20.03[4][$ b][[vi] at 20-198.15 through 20-198.19 (cited in note 3).

208. 35 USC $\$ 285$.

209. See text accompanying note 169 .

210. See Pure Oil Co. $v$ Paragon Oil Co., 117 USPQ 321, 328-29 (ND Ohio 1950).

211. Stuart v Collins, 489 F Supp 827, 833-34 (SDNY 1980). This is a thoughtful opinion by Judge Leval that also denied an injunction on the ground that defendant's complete appropriation of a little-used mark rendered it no longer useful to the plaintiff. Id at 835.

212. It is possible that "the above circumstances" phrase refers only to the two-way adjustment of profits. But James Koelemay thinks that it includes both damages and profits. See Koelemay, 72 Trademark Rptr at 519 n356 (cited in note 178). 
not penalize the defendant? Indeed, courts refer to enhancement as a deterrent. ${ }^{213}$

The seeming contradiction of authorizing triple damages and then emphasizing that they must be compensatory can be explained. The key to the explanation is the word "penal." To say that an award is "penal" is to discredit it. Thus, courts will not enforce the penal judgments of another sovereign. ${ }^{214}$ Penal impositions are strictly construed. ${ }^{215}$ Consequently, the 1909 Copyright Act asserted that its statutory damages provision, with a $\$ 250$ minimum, "shall not be regarded as a penalty."216 The Supreme Court interpreted the "in lieu" damages of the 1909 Act as authorizing recoveries where damages were impractical to prove, without their incurring the stigma of being "penal."'217

Koelemay explained that the drafters of the Lanham Act in 1946 borrowed the idea from the Copyright Act, and embellished it with the "shall constitute compensation" phrase. ${ }^{218}$ So, it seems quite probable that the "not a penalty" clause is not an admonition at all. Rather, it is simply an invitation to increase damages in appropriate cases. Courts that ignore the clause ${ }^{219}$ are not disrespectful of it.

Conscientious courts do take seriously the seeming constraint that flows from a simple reading of the clause, however. Two recent court of appeals decisions are on point. Jurgens $v$. McKasy ${ }^{220}$ was tried in the Federal Circuit because the plaintiff had a patent on the wind-inflated goose that was a popular yard ornament for a while. The plaintiff prevailed both on its patent and on trade-dress infringement claims under Lanham Act section 43(a).221 The court doubled the patent damages and tripled the Lanham Act damages. ${ }^{222}$ The court of appeals had no difficulty with the doubled patent damages, but balked at increasing the Lanham Act damages (as found by the jury), because the trial court had said that the trebling was punitive. Apparently, the Federal Circuit equated "punitive" with "penal," or rather thought that the regional circuit would do so. ${ }^{223}$

In another trade dress case, ${ }^{224}$ which involved the appearance of restaurants, the trial court doubled a jury award of $\$ 934,000$. The Fifth

213. See, for example, Polo Fashions $v$ Rabanne, 661 F Supp 89, 96 (SD Fla 1986).

214. A classic statement of this principle can be found in Huntington $v$ Attrill, 146 US 657, 666-78 (1892).

215. See Koelemay, 72 Trademark Rptr at $522 \mathrm{n} 377$ (cited in note 178).

216. Copyright Act of $1909 \S 25(\mathrm{~b}), 35$ Stat at 1075.

217. Douglas $v$ Cunningham, 294 US 207, 209-10 (1935).

218. Koelemay, 72 Trademark Rptr at 522-23 (cited in note 178).

219. See id at $517 \mathrm{n} 346$.

220. 927 F2d 1552 (Fed Cir 1991).

221. 15 USC $\$ 1125(\mathrm{a})$.

222. The opinion does not provide any amounts except for an $\$ 800,000$ punitive damage award made pursuant to state law, awarded by the jury and set aside by the judge.

223. The Federal Circuit must defer to the law of the regional circuit in trademark cases. Id at 1564.

224. Taco Cabana Intl Inc. v Two Pesos, Inc., 932 F2d 1113 (5th Cir 1991), cert granted Jan 27, 1992. 
Circuit was troubled by the apparent anomaly of the "not a penalty" clause, but rose above its unease as it had once previously. ${ }^{225}$

If the interpretation of the "not a penalty" clause suggested above 226 is correct, there is nothing to worry about. The Federal Circuit has been too cautious. All the clause does is declare that enhanced damages and profits authorized by Congress are "not a penalty." 227 It does not require courts to refrain from awarding them.

It has recently been settled that punitive damages, as such, cannot be given in Lanham Act cases. ${ }^{228}$ Some commentators have suggested that a litigant use the common law "unfair competition" route that recognizes essentially the same rights as does the trademark statute, and that by travelling that road she can obtain punitive damages. ${ }^{229}$ Examination of the few appellate cases cited for this proposition does not wholly support it except in one instance. ${ }^{230}$

In a 1980 decision in the Eighth Circuit, ${ }^{231}$ the plaintiff contended that section 35, the remedies provision of the Lanham Act, was not exclusive in a suit based on section 43 (a) of the Act, and that plaintiff was entitled to "all remedies available in the common law, including punitive damages." The court replied, "We cannot agree . . . [because] section 35 should be applied in the manner in which it is applied to all Lanham Act suits; it should be viewed as setting forth the exclusive remedy. Accordingly, the district court has broad discretion to fashion a just remedy consistent with section 35 , including treble damages." 232

225. Boston Professional Hockey v Dallas Cap, 597 F2d 71, 77 (5th Cir 1979). The Taco Cabana court suggested that there might be undercompensated damages in a case like Boston Professional Hockey, which it characterized as one of "brazen infringement and rapid market foreclosure." 932 F2d at 1128.

226. And which is implicit, I think, in Koelemay's analysis. See Koelemay, 72 Trademark Rptr 458 (cited in note 178 ).

227. See 15 USC $\$ 1117$ (b) (requiring triple profits or damages for using counterfeit marks "unless the court finds extenuating circumstances"). One dares not ponder what a "counterfeit" is. See General Electric Co. $v$ Speicher, 877 F2d 531, 534-35 (7th Cir 1989) (inclusion of non-trademarked inserts in boxes stamped with registered trademark held to "counterfeit" trademark within meaning of Lanham Act). On the sharp bite of $\$ 1117$ (b), see Judge Posner's decision on Louis Vuitton S.A. v Lee, 875 F2d 587, 588 (7th Cir 1989).

228. Getty Petroleum Corp. v Bartco Petroleum Corp., 858 F2d 103, 113 (2d Cir 1988).

229. McCarthy 2 Trademarks and Unfair Competition $\S 30: 29$ at 517-18 (cited in note 3).

230. Transgo, Inc. $v$ Ajac Transmission Parts Corp., 768 F2d 1001 (9th Cir 1985), which combined copyright, trademark, and unfair competition claims. The jury was stingy with actual damages but awarded $\$ 100,000$ punitive damages, which was upheld. Id at 1024 . The court never mentioned the applicability of the Lanham Act. See also Universal City Studios v Nintendo Co. Lid., 797 F2d 70 (2d Cir 1986), which also combined copyright, trademark (with Lanham Act references), and unfair competition. The punitive damages award, upheld under New York standards, was described as justified by a "tortious interference counterclaim." Id at 77-78. Accord, Bauer Lamp Co., Inc. v Schaffer, 941 F2d 1165 (11th Cir 1991) (\$ 43(a) design case). Big $O$ Tire Dealers, Inc. $v$ Goodyear Tire E Rubber Co., 561 F2d 1365, 1373 (10th Cir 1977), described the punitive damages as being for "trademark disparagement." The court declined to award defendant's profits, even though the infringement was "wanton and reckless," because that would overcompensate the plaintiff. Id at 1374-76. A very similar reverse confusion case, Zasu Designs $v$ L'Oreal S.A., 9 USPQ 2d 1972, 1979 (ND Ill 1988), included a punitive damage award of $\$ 1$ million "under the law of Illinois."

231. Metric E' Multistandard Components v Metrics, Inc., 635 F2d 710 (8th Cir 1980).

232. Id at 716 . 


\section{VII}

\section{Conclusion}

Nothing remotely cosmic emerges from this survey, nor anything surprising. Perhaps the nearest thing to a surprise is the agreeable impression that the courts pay close attention to and faithfully follow the governing statutes, exhibiting none of the veiled hostility to statutes in which judges are sometimes said to indulge. This should not surprise anyone, either. Patents and copyrights have been creatures of statute from the beginning of the republic. ${ }^{233}$ The first comprehensive trademark statute, the Lanham Act of 1946, has yet to reach the half-century mark; and it is not exclusive of common law rights. Yet the Lanham Act is not only the home of registered marks. The metamorphosis of section $43(\mathrm{a})$ as a resort for unregistered marks ${ }^{234}$ has made the federal forum, and federal law, the dominant backdrop for trademark litigation.

A historic strain that has demonstrated remarkable staying power is the influence of equity, explicitly endorsed in some of the statutes. The courts seem to take this tradition seriously. It justifies an attitude of flexibility. It also seems to stimulate a somewhat moralistic preoccupation with bad faith and willful behavior by infringers. I have no difficulty with most manifestations of judicial distaste or indignation. In every field that we have traversed, the range of infringing behavior is so extensive, from innocent to outrageous, that it would be regrettable if judges (and juries) were held to the precise limits of a defaulted contract for winter wheat.

Despite the many variations noted, the main themes of the three statutes are essentially the same. The only major anomaly is the mysterious 1946 denial of defendants' profits in patent cases. Accountings to establish those profits may be complicated, but they are possible. Reconstruction of a plaintiff's losses is often an exercise in speculation; it deals with transactions that never happened. I am mindful that the most thorough study of profit awards and other elements of trademark recoveries calls profits awards a "dinosaur"; 235 but dinosaurs are rather in vogue nowadays. It is possible that the denial of defendants' profits in patent law is partly responsible for the too elaborate criteria that must be satisfied in calculating damages and hypothetical reasonable royalties.

Injunctions, the starting point of this article, especially display the lasting imprint of equity. The significant development in this area is the trend toward similar availability of injunctive relief in all three fields, in marked contrast to the disparate treatment that Alan Latman found in 1970. This has required facilitating the injunctive process in patent cases, and inhibiting it in

233. Copyright, to be sure, had a common law side for unpublished works until they were brought into the statute in the 1976 General Revisions. See Ralph S. Brown, Jr., Unification: $A$ Cheerful Requiem for Common Law Copyright, 24 UCLA L Rev 1070 (1977).

234. See Joseph P. Bauer, A Federal Law of Unfair Competition: What Should be the Reach of Section 43(a) of the Lanham Act?, 31 UCLA L Rev 671 (1984).

235. Koelemay, 72 Trademark Rptr at 537 (cited in note 178). 
copyright. In copyright, the main impetus toward a degree of caution in hurling injunctions is a welcome if belated one: an understanding that the first amendment has a lot to say to copyright. ${ }^{236}$ All copyright, after all, is speech. 237

236. Recently, there has been a trickle of first amendment concern in connection with the parodic or satiric use of others' trademarks. See Robert C. Denicola, Trademarks as Speech: Constitutional Implications of the Emerging Rationales for the Protection of Trade Symbols, 1982 Wis L Rev 158; Harriette K. Dorsen, Satinc Appropriation and the Law of Libel, Trademark and Copyright: Remedies without Wrongs, 65 Bost U L Rev 923 (1985).

237. A final personal note: It has been a bizarre experience, in looking up scores of cases, mostly to be interested only in the last page or two of an opinion. That illustrates the observation at the beginning of this article that remedies come at the end. 